University of Wollongong

Research Online

Australian Institute for Innovative Materials -

Papers

Australian Institute for Innovative Materials

$1-1-2020$

The Cathode Choice for Commercialization of Sodium-Ion Batteries:

Layered Transition Metal Oxides versus Prussian Blue Analogs

Qiannan Liu

University of Wollongong, qiannan@uow.edu.au

Zhe Hu

University of Wollongong

Mingzhe Chen

University of Wollongong

Chao Zou

Huile Jin

See next page for additional authors

Follow this and additional works at: https://ro.uow.edu.au/aiimpapers

Part of the Engineering Commons, and the Physical Sciences and Mathematics Commons

Research Online is the open access institutional repository for the University of Wollongong. For further information contact the UOW Library: research-pubs@uow.edu.au 


\title{
The Cathode Choice for Commercialization of Sodium-Ion Batteries: Layered Transition Metal Oxides versus Prussian Blue Analogs
}

\author{
Abstract \\ 2020 WILEY-VCH Verlag GmbH \& Co. KGaA, Weinheim With the unprecedentedly increasing demand for \\ renewable and clean energy sources, the sodium-ion battery (SIB) is emerging as an alternative or \\ complementary energy storage candidate to the present commercial lithium-ion battery due to the \\ abundance and low cost of sodium resources. Layered transition metal oxides and Prussian blue analogs \\ are reviewed in terms of their commercial potential as cathode materials for SIBs. The recent progress in \\ research on their half cells and full cells for the ultimate application in SIBs are summarized. In addition, \\ their electrochemical performance, suitability for scaling up, cost, and environmental concerns are \\ compared in detail with a brief outlook on future prospects. It is anticipated that this review will inspire \\ further development of layered transition metal oxides and Prussian blue analogs for SIBs, especially for \\ their emerging commercialization.

\section{Disciplines} \\ Engineering | Physical Sciences and Mathematics

\section{Publication Details} \\ Liu, Q., Hu, Z., Chen, M., Zou, C., Jin, H., Wang, S., Chou, S., Liu, Y. \& Dou, S. (2020). The Cathode Choice for \\ Commercialization of Sodium-Ion Batteries: Layered Transition Metal Oxides versus Prussian Blue \\ Analogs. Advanced Functional Materials,

\section{Authors} \\ Qiannan Liu, Zhe Hu, Mingzhe Chen, Chao Zou, Huile Jin, Shun Wang, Shulei Chou, Yong Liu, and Shi Xue \\ Dou
}




\section{WILEY-VCH}

DOI: 10.1002/ ((please add manuscript number))

Article type: Review

\section{The Cathode Choice for Commercialization of Sodium-Ion Batteries: Layered Transition Metal Oxides vs. Prussian Blue Analogues}

Qiannan Liu, Zhe Hu, Mingzhe Chen, Chao Zou, Huile Jin, Shun Wang, * Shu-Lei Chou, * Yong Liu, * and Shi-Xue Dou

Dr. Q. Liu, Prof. C. Zou, Dr. H. Jin, Prof. S. Wang

College of Chemistry and Materials Engineering, Wenzhou University, Wenzhou, Zhejiang 325027, China

Email: shunwang@wzu.edu.cn

Dr. Q. Liu, Dr. Z. Hu, Dr. M. Chen, Prof. S.-L. Chou, Prof. S.-X. Dou

Institute for Superconducting and Electronic Materials, Australian Institute for Innovative

Materials, University of Wollongong, Innovation Campus, Squires Way, North Wollongong,

NSW 2522, Australia

E-mail: shulei@uow.edu.au

Prof. Y. Liu

School of Ophthalmology and Optometry, School of Biomedical Engineering, Wenzhou Medical University, 270 Xueyuanxi Road, Wenzhou 325027, China

Email: yongliu@wmu.edu.cn

Keywords: commercialization, cathodes, sodium ion batteries, transition metal oxides, Prussian blue analogues

Abstract: With the unprecedentedly increasing demand for renewable and clean energy sources, the sodium ion battery is emerging as an alternative or complementary energy storage candidate to the present commercial lithium ion battery due to the abundance and low cost of sodium resources. Layered transition metal oxides and Prussian blue analogues are reviewed in terms of their commercial potential as cathode materials for sodium ion batteries (SIBs). Recent progresses in research on their half cells and full cells for ultimate application in SIBs are summarized. In addition, their electrochemical performance, suitability for scaling up, cost, and environmental concerns are compared in detail and with a view to their future prospects. It is anticipated that this review will inspire further development of layered transition metal oxides and Prussian blue analogues for sodium ion batteries, especially for their emerging commercialization. 


\section{WILEY-VCH}

\section{Introduction}

As a warming world shifts from fossil fuels toward renewable energy sources, industrial market forecasts an insatiable demand for battery systems that can store power and provide electricity in a clean and sustainable way. ${ }^{[1]}$ As one of the most important transport aspects in people's daily life, electric vehicle production, nowadays mainly powered by lithium ion batteries (LIBs), is expected to increase to 24.4 million by $2030 .{ }^{[2]}$ The lithium consumption forecast based on only electric vehicle increase from 2020 to 2050 is shown in Figure 1a. ${ }^{[3]}$ The resulting spiralling demand and cost of lithium resources, which are expensive to mine and refine, looms large. Moreover, practically productive lithium reverses are unevenly distributed and restricted in certain areas, such as South America, Australia, China, and US. ${ }^{[4-5]}$ The global energy storage market for batteries will reach to $\$ 13.13$ billion by 2023 from the forecast by GlobalData. It is thus extremely important and urgent to find other candidates that are practically achievable and commercially suitable for the battery industry.

The race to develop a high-efficiency, low-cost, and easily accessible alternative to the present ubiquitous LIBs is going on in laboratories all over the world. Among all the candidates, sodium-ion batteries (SIBs) are especially attractive due to the abundance and even distribution of sodium resources. ${ }^{[7-9]}$ Moreover, they are cheaper, safer, and possible to yield faster charging, as well as having a wider operating temperature range $\left(-20^{\circ} \mathrm{C}\right.$ to $\left.+60^{\circ} \mathrm{C}\right)$ compared to LIBs. Figure 1b shows the thermal output of a SIB cell at $0 \mathrm{~V}(0 \%$ state of charge (SOC)) and a LIB battery at $100 \%$ SOC, heated under the same conditions. The amount of heat generated by the $\mathrm{LiFePO}_{4}$ cell is over 15 times greater than that generated by the SIB cell. ${ }^{[6]}$ In addition, aluminium is inactive in sodium chemistry. Thus $\mathrm{Al}$ foil can be used as the current collector for the cathode as well as for the anode in a SIB, which avoids the need for a Cu current collector as in a LIB, and greatly reduces the whole cost and weight of a SIB. Due to the heavier nature 


\section{WILEY-VCH}

of Na compared to Li, SIBs are more suitable for large-scale stationary energy storage devices. ${ }^{[7}$, 9]

The major challenges for commercialization of SIBs are the low energy density and limited cycle life of electrode materials. The cathode, as one of the essential components of a battery, is especially important and greatly determines the energy density and cycle life. It is difficult to simply duplicate a cathode from its lithium counterpart to produce electrodes for SIBs due to the larger radius and slightly different chemistry between $\mathrm{Na}^{+}$ions and $\mathrm{Li}^{+}$ions. For example, $\mathrm{NaFePO}_{4}$ does not show comparable capacity although $\mathrm{LiFePO}_{4}$ is one of the most used cathodes for commercial LIBs. ${ }^{[10]} \mathrm{NaCrO}_{2}$ can deliver a highly reversible capacity of $\sim 120 \mathrm{mAh}$ $\mathrm{g}^{-1}$, while $\mathrm{LiCrO}_{2}$ is electrochemically inactive. ${ }^{[11]}$ Different cathode materials, including transition metal $(\mathrm{M})$ oxides $\left(\mathrm{Na}_{x} \mathrm{MO}_{2}, x \leq 1\right),{ }^{[12-26]}$ hexacyanoferrates $(\mathrm{HCF})$ or Prussian blue and its analogues (PBAs), ${ }^{[27-32]}$ polyanion compounds ${ }^{[33-47]}$ and organic compounds ${ }^{[48-57]}$ have been widely studied for SIBs. The substaintial growth of exploration on full cell systems, which serve as a bridge between laboratory studies and practical application, clearly reveals the unprecedented interest in and expectation for the commercialization of SIBs (Figure 1c). The study of full cell performance is not enough, however, since the cost, yield, environmental friendliness and recycling of materials also need to be considered for the final commercialization of SIBs. For example, it is difficult to get large-yield and high-quality coatings for nano-sized materials in mass production.

There is an enormous number of papers reviewing the progress of electrode materials for SIBs, and some of them have mentioned the potential of layered $\mathrm{Na}_{\mathrm{x}} \mathrm{MO}_{2}$ or $\mathrm{PBAs}$ as cathode materials for SIBs. ${ }^{[7,58-92]}$ Only a few of them, however, involve the commercial aspect. In this review, both layered $\mathrm{Na}_{\mathrm{x}} \mathrm{MO}_{2}$ and PBAs are discussed in detail and compared with regard to their commercialization potential. The recent status of research, including the progress on half cells and full cells is summarized. For commercialization purpose, their suitability for mass production, electrochemical performance, cost, and environmental concerns are compared in 


\section{WILEY-VCH}

detail. It is anticipated to shed light on and accelerate their progress toward the practical battery market in the near future.

\section{Overview of layered $\mathrm{Na}_{x} \mathrm{MO}_{2}$ and PBAs}

An ideal cathode should possess the following properties for practicability: (1) can host a large amount of alkaline ions (high specific capacity); (2) shows high redox potential; (3) maintains structural integrity during cycling (long lifespan); (4) has a large diffusion coefficient for $\mathrm{Na}^{+}$ ions and high electronic conductivity (good rate performance); (5) has high chemical and thermal stability, and is highly compatible with electrolytes (good safety); (6) is easily accessible, environmentally friendly, and cost-effective. In these aspects, layered $\mathrm{Na}_{\mathrm{x}} \mathrm{MO}_{2}$ and PBAs demonstrate their prospects to some extent and have greatly attracted researchers' attentions all over the world.

Pioneering work on the development of SIB cathodes involved $\mathrm{Na}_{x} \mathrm{MO}_{2}$ compounds, simulating their lithium counterparts. It has been well acknowledged that the electrochemical performance of an electrode material is closely related to its intrinsic crystal structure. Tunnel structured $\mathrm{Na}_{x} \mathrm{MO}_{2}$, mainly $\mathrm{Na}_{0.44} \mathrm{MnO}_{2}$, is excluded here, since it can only reversibly deintercalate and intercalate a small number of $\mathrm{Na}^{+}$ions and shows limited specific capacity. ${ }^{[95-}$ ${ }^{97]}$ Figure 2a illustrates the structure of layered $\mathrm{Na}_{x} \mathrm{MO}_{2}$ compounds, which are made up of sheets of $\mathrm{MO}_{6}$ octahedra, and can mainly be classified into P2- and O3-phases, based on the prismatic or octahedral $\mathrm{Na}$ environment and the number of oxygen stacking sequences. ${ }^{[98]} \mathrm{O} 3-$ type materials have larger $\mathrm{Na}$ content than P2-phase materials in general. The large $\mathrm{MO}_{6}$ sheets provide two-dimensional transport channels for the extraction/insertion of $\mathrm{Na}^{+}$ions between them, providing high specific capacity to $\mathrm{Na}_{x} \mathrm{MO}_{2}$. When $\mathrm{Na}^{+}$ions are partly extracted from the framework, $\mathrm{P} 2$-type $\mathrm{Na}_{x} \mathrm{MO}_{2}$ may experience a $\mathrm{P} 2-\mathrm{O} 2$ phase transformation or form a distorted structure at high voltage. O3-type $\mathrm{Na}_{x} \mathrm{MO}_{2}$ may undergo an $\mathrm{O} 3-\mathrm{P} 3$ transition after $\sim 25 \% \mathrm{Na}$ ion extraction and even more complex phase transfers, such as the $\mathrm{O} 3 \rightarrow \mathrm{O} 3+\mathrm{P} 3 \rightarrow \mathrm{O} 1+\mathrm{P} 3$ 


\section{WILEY-VCH}

phase transformation of $\mathrm{NaFe}_{0.25} \mathrm{Mn}_{0.25} \mathrm{Ni}_{0.25} \mathrm{Ti}_{0.25} \mathrm{O}_{2}$ during its electrochemical cycling process. ${ }^{[99]}$ The P3-type structure can be directly obtained if the synthesis temperature is lower than $800{ }^{\circ} \mathrm{C}$, but the product shows inferior performance. ${ }^{[100]}$ The transformation from $\mathrm{O} 2$ or $\mathrm{P} 2$ to $\mathrm{O} 3$ or $\mathrm{P} 3$ is not possible due to the large energy needed to break Mn-O bonds. ${ }^{[101]}$ Limited cycle life, irreversible phase transitions, and air sensitivity inhibit the practical application of layered $\mathrm{Na}_{x} \mathrm{MO}_{2} \cdot{ }^{[77]}$ Furthermore, the low Na content in P2-type material indicates an initial Coulombic efficiency higher than $100 \%$ in half cells and low Coulombic efficiency of the anode in full cells. Pre-sodiation is often utilized for sodium compensation but is unwelcomed due to its complexity and increased cost. Layered $\mathrm{Na}_{x} \mathrm{MO}_{2}$ with high $\mathrm{Na}$ content, high air stability and long lifespan are always expected.

Prussian blue $\left(\mathrm{PB}, \quad \mathrm{Fe}\left[\mathrm{Fe}(\mathrm{CN})_{6}\right] \cdot n \mathrm{H}_{2} \mathrm{O}\right)$ and its analogues (PBAs, $\mathrm{A}_{x} \mathrm{M}\left[\mathrm{M}^{\prime}(\mathrm{CN})_{6}\right]_{(1-y)} \cdot \square y^{*} \cdot n \mathrm{H}_{2} \mathrm{O}$; A: an alkali metal, M: an N-coordinated transition metal ion, $\mathrm{M}^{\prime}$ : a C-coordinated transition metal ion, and $\square$ : vacancies occupied by coordinating water; $0 \leq x \leq$ 2, $0 \leq y<1)$ are a large family of transition metal cyanides and considered to be promising cathode candidates for SIBs. The typical crystal structures of PB and typical PBAs $\left(\mathrm{Na}_{x} \mathrm{MnFe}(\mathrm{CN})_{6}\right)$ are illustrated in Figure 2b. Water exists in three kinds of forms in the PBAs framework, namely the adsorbed water on the surface, the zeolitic water in the interstitial sites, and the coordinated water that is chemically boned with the metal ions. The adsorbed and zeolitic water is easy to remove since they only have physical interaction with PBAs framework. In contrast, the coordinated water is difficult to remove due to its coordination with the metal ions in PBAs structure. Influenced by the concentration of alkaline ions and the amount of zeolitic water in the framework, PBAs exhibit three types of structure: cubic, monoclinic and rhombohedral. Normally, the alkaline-deficient PBAs show cubic structure, while alkaline-rich PBAs usually present monoclinic phase. ${ }^{[75]}$ Due to greatly reduced amount of water, $\mathrm{Na}_{2-\delta} \mathrm{MnFe}(\mathrm{CN})_{6}$ changed from monoclinic to rhombohedral phase after dehydration treatment and the electrochemical performance was greatly enhanced. ${ }^{[27]}$ Tetragonal phase may also be 


\section{WILEY-VCH}

formed during the $\mathrm{Na}^{+}$de-insertion/insertion processes. ${ }^{[27]}$ Because the open framework provides large ionic channels, PB and PBAs (with PBAs used to represent both from now on) can accommodate and reversibly intercalate large amounts of $\mathrm{Na}^{+}$ions and demonstrate excellent potential. Challenges for practical application, however, still exist. Since PBAs are normally based on liquid chemistry, there are always large amounts of vacancies occupied by coordinated water formed in the crystal framework, resulting from the rapid precipitation process. The intrinsic vacancies and coordinated water in PBAs may induce lattice distortion and even structural collapse during $\mathrm{Na}^{+}$extraction/insertion processes, resulting in low specific capacity, low energy efficiency, and electrochemical performance deterioration. Strategies exploiting to reduce the amount of water in PBAs include coarsening the particles to reduce adsorbed water, dehydrating the PBA samples, introducing more alkaline ions into the framework for reduced amount of zeolitic water, and reducing the amount of vacancies for reduced coordinated water. ${ }^{[75]}$ Obtaining perfect PBAs with few vacancies and little water content remains an important target.

\section{Current progress on layered $\mathrm{Na}_{x} \mathrm{MO}_{2}$}

Remarkable achievements have been made on layered transition metal oxide cathodes for SIBs. Different metal elements endow these materials with different characteristics, such as the abundance and toxicity of $\mathrm{V}$ and $\mathrm{Cr}$, the high capacity and distorting Jahn-Teller effect of $\mathrm{Mn}$, the abundance of $\mathrm{Fe}$, the large voltage range of $\mathrm{Ni}$, the high electronic conductivity and high price of $\mathrm{Co}$, and the inert activity and strong electronegativity of $\mathrm{Zn} .{ }^{[78]}$ From the $\mathrm{Na}_{x} \mathrm{MO}_{2}$ with a single transition metal element, studies moved on to layered $\mathrm{Na}_{x} \mathrm{MO}_{2}$ with binary, ternary and multiple transition metals to take advantage of their synergistic effects with the aim of finding eligible candidates with enhanced capacity, long cycle life, and air stability.

$\mathrm{NaFeO}_{2}$ was demonstrated to show good capacity retention with a reversible capacity of 80 $\mathrm{mAh} \mathrm{g}^{-1}$ below $3.4 \mathrm{~V}$. This reversibility, however, significantly deteriorated because of the 


\section{WILEY-VCH}

irreversible structural change at higher voltage above $3.5 \mathrm{~V}$ (Figure 3a, b). ${ }^{[102]}$ Limiting the cut-off voltage is performed to suppress structural change and ensure sufficient cycle life. $\mathrm{Na}_{x} \mathrm{MnO}_{2}, \mathrm{Na}_{x} \mathrm{NiO}_{2}, \mathrm{Na}_{x} \mathrm{CoO}_{2}, \mathrm{Na}_{x} \mathrm{CrO}_{2}$, and $\mathrm{Na}_{x} \mathrm{VO}_{2}$ also display reversible capacities. ${ }^{[24,98,}$ ${ }^{105-107]}$ Partial Co replacement of $\mathrm{Fe}$ in $\mathrm{NaFeO}_{2}$ was able to suppress its irreversible phase transition. ${ }^{[108]} \mathrm{NaFe}_{0.5} \mathrm{Co}_{0.5} \mathrm{O}_{2}$ delivered a reversible capacity of $\sim 160 \mathrm{mAh} \mathrm{g}^{-1}$ with good capacity retention and more than $75 \%$ retention of discharge capacity, even at a $10 \mathrm{C}$ rate. ${ }^{[109]}$ P2- $\mathrm{Na}_{0.67} \mathrm{Fe}_{0.5} \mathrm{Mn}_{0.5} \mathrm{O}_{2}$ was reported to display a reversible capacity of $190 \mathrm{mAh} \mathrm{g}^{-1}$ resulting from the $\mathrm{Fe}^{4+} / \mathrm{Fe}^{3+}$ conversion. ${ }^{[110]}$ The introduction of $\mathrm{Ni}$ into the structure of $\mathrm{Na}_{x} \mathrm{Mn}_{0.5} \mathrm{Fe}_{0.5} \mathrm{O}_{2}$ gives it an enhanced average potential. Ni-substituted $\mathrm{Na}_{0.67} \mathrm{Mn}_{0.6} \mathrm{Ni}_{0.1} \mathrm{Fe}_{0.3} \mathrm{O}_{2}$ and $\mathrm{Na}_{0.67} \mathrm{Mn}_{0.65} \mathrm{Ni}_{0.15} \mathrm{Fe}_{0.2} \mathrm{O}_{2}$ displayed better structural stability and suppressed air sensitivity toward ambient atmosphere (Figure 3c). ${ }^{[103]}$ A quaternary transition metal oxide, $\mathrm{Na}\left[\mathrm{Ni}_{0.32} \mathrm{Fe}_{0.13} \mathrm{Co}_{0.15} \mathrm{Mn}_{0.40}\right] \mathrm{O}_{2}$, exhibited higher discharge capacity than its respective ternary constituents, $\mathrm{Na}\left[\mathrm{Ni}_{0.25} \mathrm{Fe}_{0.25} \mathrm{Mn}_{0.5}\right] \mathrm{O}_{2}$ and $\mathrm{Na}\left[\mathrm{Ni}_{0.4} \mathrm{Co}_{0.3} \mathrm{Mn}_{0.3}\right] \mathrm{O}_{2}$ (Figure 3d), because it benefits from the synergetic effects towards high capacity induced by Fe in its composition and the structural stabilization induced by Co substitution. ${ }^{[104]} \mathrm{Na}_{x} \mathrm{MO}_{2}$ composites with mixed phase may possess unprecedented features. ${ }^{[111-115]}$ Combining the characteristics of $\mathrm{P} 2$ and $\mathrm{P} 3$ phases and the highly reversible structural evolution from $\mathrm{P} 2 / \mathrm{P} 3$ to $\mathrm{P} 2 / \mathrm{OP} 4, \mathrm{P} 2 / \mathrm{P} 3-$ $\mathrm{Na}_{0.7} \mathrm{Li}_{0.06} \mathrm{Mg}_{0.06} \mathrm{Ni}_{0.22} \mathrm{Mn}_{0.67} \mathrm{O}_{2}$ was able to deliver a high reversible capacity of $119 \mathrm{mAh} \mathrm{g}{ }^{-1}$ and a high operating voltage of $3.53 \mathrm{~V}$ with a superior initial Coulombic efficiency of 94.8\% ${ }^{[116]}$ Figure 3e shows the relationship among the compositions, average voltages, and capacities of typical layered $\mathrm{Na}_{x} \mathrm{MO}_{2}$ in half-cell systems. The elements contained and the particular structures greatly determine the energy density. Mn-based materials are preferable, especially those with more than one kind of transition metal element.

The study on full cells of layered $\mathrm{Na}_{x} \mathrm{MO}_{2}$ are mainly focus on those with more than one type of transition metal element. A full cell assembled from $\mathrm{Co} / \mathrm{Ni}$-free $\mathrm{Na}_{0.9}\left[\mathrm{Cu}_{0.22}^{\mathrm{II}} \mathrm{Fe}^{\mathrm{IIII}}{ }_{0.30} \mathrm{Mn}^{\mathrm{III}}{ }_{0.16} \mathrm{Mn}^{\mathrm{IV}}{ }_{0.32}\right] \mathrm{O}_{2}$ cathode and hard carbon anode was reported to deliver 


\section{WILEY-VCH}

a reversible capacity of $\sim 300 \mathrm{mAh} \mathrm{g}^{-1}$ (based on the mass of the anode) at a current rate of $0.5 \mathrm{C}$ (Figure 4a). ${ }^{[117]} \mathrm{A}$ high average operation voltage of $3.2 \mathrm{~V}$ was obtained together with a high energy density of $210 \mathrm{Wh} \mathrm{kg}^{-1}$ based on the total mass of cathode and anode. An O3$\mathrm{Na}\left[\mathrm{Li}_{0.05}\left(\mathrm{Ni}_{0.25} \mathrm{Fe}_{0.25} \mathrm{Mn}_{0.5}\right)_{0.95}\right] \mathrm{O}_{2} / /$ hard carbon full cell offered $76 \%$ capacity retention after 200 cycles (Figure 4b). ${ }^{[18]}$ Another SIB full battery assembled using P2/P3$\mathrm{Na}_{0.7} \mathrm{Li}_{0.06} \mathrm{Mg}_{0.06} \mathrm{Ni}_{0.22} \mathrm{Mn}_{0.67} \mathrm{O}_{2}$ and hard carbon exhibited a high average voltage of $3.36 \mathrm{~V}$ with an energy density up to $218 \mathrm{Wh} \mathrm{kg}^{-1} \cdot{ }^{[116]}$ Sodium compensation is sometimes exploited for P2type $\mathrm{Na}_{x} \mathrm{MO}_{2}$ compounds due to their low $\mathrm{Na}$ content when implementing full cell construction of SIBs. A $\mathrm{NaPO}_{3}$ coating layer on $\mathrm{P} 2-\mathrm{Na}_{2 / 3} \mathrm{Ni}_{1 / 3} \mathrm{Mn}_{2 / 3} \mathrm{O}_{2}$ was reported to capable of scavenging $\mathrm{HF}$ and $\mathrm{H}_{2} \mathrm{O}$ in the electrolyte, leading to less by-product formation during cycling processes. A full cell assembled from $\mathrm{NaPO}_{3}$-coated $\mathrm{P} 2-\mathrm{Na}_{2 / 3} \mathrm{Ni}_{1 / 3} \mathrm{Mn}_{2 / 3} \mathrm{O}_{2}$ cathode and hard carbon anode exhibited higher specific capacity (Figure 4c) and a larger capacity retention of $73 \%$ after 300 cycles, compared with the $22 \%$ capacity retention of a bare $\mathrm{Na}_{2 / 3} \mathrm{Ni}_{1 / 3} \mathrm{Mn}_{2 / 3} \mathrm{O}_{2} / /$ hard carbon full cell. ${ }^{[119]}$ Pre-sodiation treatment of both cathode and anode were carried out in this study. $\mathrm{NaN}_{3}$ was also used as a sacrificial salt to compensate the sodium deficiency in layered $\mathrm{Na}_{x} \mathrm{MO}_{2}$. A $60 \%$ increase in the reversible capacity of $\mathrm{P} 2-\mathrm{Na} \mathrm{N}_{0.67}\left[\mathrm{Fe}_{0.5} \mathrm{Mn}_{0.5}\right] \mathrm{O}_{2}$ was achieved with $10 \%$ $\mathrm{NaN}_{3}$ addition (Figure 4d). ${ }^{[120]}$

It is well acknowledged that the battery performance in a half-cell is not necessarily consistent with and can even be greatly different from that in a full cell. In full sodium ion cells, the $\mathrm{Na}^{+}$ions are only provided by the cathode side. The effect of the $0.3 \mathrm{~V}$ lower voltage for SIBs than for LIBs in the case of half-cells disappears in the case of full cells. ${ }^{[7]}$ Figure $4 \mathbf{e}$ shows the specific energy of some $\mathrm{Na}_{x} \mathrm{MO}_{2}$ in half-cell and full-cell configurations based on the cathode weight only. ${ }^{[67]}$ It can be seen that O3-phase cathodes show much less discharge energy reduction than P2-phase cathodes when full cells instead of half cells are assembled. Due to the intrinsic sodium deficiency of P2 phase, its attractive energy density of 500-550 Wh $\mathrm{kg}^{-1}$ in half cells is reduced to $\sim 300 \mathrm{Wh} \mathrm{kg}^{-1}$ in full cells. Adding a pre-sodiation step may 


\section{WILEY-VCH}

alleviate the problem to some extent, ${ }^{[121]}$ but will undoubtedly increases the cost and complicates the cell manufacturing process. Thus, O3-phase is preferable for the full cell configuration. Several prototype SIBs using O3-type $\mathrm{Na}_{x} \mathrm{MO}_{2}$ cathodes have been reported. The first cylindrical prototype was demonstrated by CNRS and RS2E, and is now being commercialized by Tiamat, exhibiting an energy density of $90 \mathrm{Wh} \mathrm{kg}^{-1}$ over 2000 cycles. ${ }^{[122]}$ In 2016, a tin-doped sodium nickelate oxide material, $\mathrm{NaNi}_{1 / 3} \mathrm{Fe}_{1 / 6} \mathrm{Mn}_{1 / 3} \mathrm{Mg}_{1 / 12} \mathrm{Sn}_{1 / 12} \mathrm{O}_{2}$, was reported by Sharp Laboratories of Europe Ltd and demonstrated 3.3 and $4.2 \mathrm{Ah}$ in pouch cells with volumetric energy densities of 211 and $250 \mathrm{Wh} \mathrm{L}^{-1}$, respectively, when assembled with hard carbon anode in SIBs. ${ }^{[123]}$ A SIBs system with a power rating of $30 \mathrm{~kW} / 100 \mathrm{kWh}$ was installed in China recently. ${ }^{[124]}$

\section{Current progress on PBAs}

Although there are various metals capable of occupying the $\mathrm{M}^{\prime}$ site in PBAs, Fe is the most commonly used element. Different $\mathrm{A}_{x} \mathrm{M}\left[\mathrm{Fe}(\mathrm{CN})_{6}\right]_{(1-y)} \cdot \square y \cdot n \mathrm{H}_{2} \mathrm{O}$ materials with $\mathrm{M}$ standing for $\mathrm{Fe}, \mathrm{Mn}, \mathrm{Ni}, \mathrm{Cu}, \mathrm{Co}$, or $\mathrm{Zn}$ were studied, with the main focus on the $\mathrm{Fe}$ - and Mn-containing ones. Fe-based PBAs, however, always suffer from poor quality due to the low crystallinity, low electronic conductivity, and side reactions with the electrolyte, resulting in unsatisfactory cycling stability and poor rate performance. Substantive efforts have been made to prepare PBAs with few vacancies, low water content, and high Na content and crystallinity.

Highly crystalline $\mathrm{Na} a_{0.61} \mathrm{Fe}\left[\mathrm{Fe}(\mathrm{CN})_{6}\right]_{0.94}$ with a low zeolite water content and a small number of $\left[\mathrm{Fe}(\mathrm{CN})_{6}\right]$ vacancies was reported, which showed a reversible specific capacity of $\sim 170 \mathrm{mAh} \mathrm{g}^{-1}$ under $25 \mathrm{~mA} \mathrm{~g}^{-1}$ with nearly $100 \%$ Coulombic efficiency (CE). ${ }^{[130]}$ Na-rich $\mathrm{Na}_{1.92} \mathrm{Fe}\left[\mathrm{Fe}(\mathrm{CN})_{6}\right]$ was successfully synthesized with $80 \%$ capacity retention after 750 cycles at $15 \mathrm{~mA} \mathrm{~g}^{-1}$ and excellent rate capability with $145 \mathrm{mAh} \mathrm{g}^{-1}$ at $1500 \mathrm{~mA} \mathrm{~g}^{-1} \cdot{ }^{[131]}$ The synergistic merits of Fe and Ni were taken advantage of and discussed (Figure 5a). ${ }^{[125]} \mathrm{Fe}-\mathrm{HCF}$ $\left(\mathrm{Na}_{1.54} \mathrm{Fe}\left[\mathrm{Fe}(\mathrm{CN})_{6}\right]_{0.96} \square_{0.04}\right)$ delivered high initial CE (ICE) of $92.1 \%$ due to its high Na content, 


\section{WILEY-VCH}

but it exhibited rapid capacity deterioration. Ni-HCF $\left(\mathrm{Na}_{0.18} \mathrm{~K}_{0.1} \mathrm{Ni}\left[\mathrm{Fe}(\mathrm{CN})_{6}\right]_{0.71} \square_{0.29}\right)$ demonstrated excellent structural stability, with $89.2 \%$ capacity retention after 600 cycles at $200 \mathrm{~mA} \mathrm{~g}^{-1}$. A core-shell Fe-HCF@Ni-HCF composite delivered a high CE of $99.3 \%$ and a reversible capacity of $79.7 \mathrm{mAh} \mathrm{g}^{-1}$ at $200 \mathrm{~mA} \mathrm{~g}^{-1}$ after 800 cycles. Komaba et al. also studied the differences among various metals (Mn, Fe, Co, and Ni) for PBAs, and further proved the structural stability of Ni-based PBAs and the high specific capacity of Fe- and Mn-based PBAs, as shown in Figure 5b. ${ }^{[126]}$ An impressively high specific capacity of $209 \mathrm{mAh} \mathrm{g}^{-1}$ was reported in $\mathrm{Na}_{2} \mathrm{Mn}^{\mathrm{II}}\left[\mathrm{Mn}^{\mathrm{II}}(\mathrm{CN})_{6}\right]$ (Figure 5c) benefiting from its three distinct $\mathrm{Na}^{+}$ion insertion steps during cycling. ${ }^{[127]}$ PBAs with multiple transition metals were also studied and showed good performance. High quality $(\mathrm{HQ})-\mathrm{Ni}_{0.3} \mathrm{Co}_{0.7}\left[\mathrm{Fe}(\mathrm{CN})_{6}\right]$ PBA (HQ-NiCoFe) was prepared using trisodium citrate, polyvinyl pyrrolidone (PVP), and $\mathrm{NaCl}$ as chelating agent, surfactant, and ion additive, which synergistically offered a controllable growth environment for PBA crystals. ${ }^{[128]}$ The HQ-NiCoFe delivered a high initial specific capacity of $\sim 110 \mathrm{~mA} \mathrm{~h} \mathrm{~g}^{-1}$ along with $\sim 83 \%$ capacity retention over 600 cycles at $750 \mathrm{~mA} \mathrm{~g}^{-1}$, which was far better than other comparable samples (Figure 5d). As a general optimization strategy, compounding PBAs with carbonaceous materials are utilized to improve the electrochemical properties. ${ }^{[129,132-135]} \mathrm{PB} @ \mathrm{C}$ demonstrated better electrochemical properties than bare PB (Figure 5e). ${ }^{[129]}$ The rate performances of some reported PB cathodes have been summarized (Figure 5f), revealing the effective performance improvement effect of forming composites with carbonaceous materials.

Full cells using PBA cathodes have been investigated and demonstrate their potential as well. ${ }^{[137]}$ Dehydrated air-stable rhombohedral $\mathrm{Na}_{1.92} \mathrm{Fe}_{2}(\mathrm{CN})_{6}$ with few $\mathrm{Fe}(\mathrm{CN})_{6}$ vacancies showed an initial discharge capacity of $119.4 \mathrm{mAh} \mathrm{g}^{-1}$, but the initial Coulombic efficiency was only 78\%. ${ }^{[131]}$ Another full cell using a $\mathrm{Ni}_{0.3} \mathrm{Co}{ }_{0.7}\left[\mathrm{Fe}(\mathrm{CN})_{6}\right]$ cathode and $\mathrm{NaTi}_{2}\left(\mathrm{PO}_{4}\right)_{3}$ anode was reported as a dual-insertion cell and delivered a reversible capacity of $\sim 110 \mathrm{mAh} \mathrm{g}^{-1}$ at a current rate of $1.0 \mathrm{C}$ without capacity fading over 300 cycles. ${ }^{[128]}$ In 2018, Novasis Energies, Inc. reported a successful $100 \mathrm{~kg}$ batch preparation and pilot line cell fabrication of PBAs, as 


\section{WILEY-VCH}

demonstrated in Figure 6. ${ }^{[136]}$ The pouch cell assembled with commercial hard carbon anode demonstrated high Coulombic efficiency and a capacity retention of $98.6 \%$ over 500 continuous cycles. It retained $83 \%$ of its capacity at $-20{ }^{\circ} \mathrm{C}$ relative to that at room temperature, indicating great commercialization prospects of PBAs. Another Chinese company, Liaoning Starry Sky Sodium-ion Battery Co., Ltd., is also focusing on the commercialization of PBAs for SIBs and has obtained great achievements.

\section{Which is better for commercialization?}

Academic and industrial organizations around the world are making substantial efforts to finally realize the commercialization of SIBs. In the following part, factors relating to the commercialisation of layered $\mathrm{Na}_{x} \mathrm{MO}_{2}$ and PBAs, including their electrochemical performance, suitability for scaling up, cost, and environmental friendliness, will be discussed and compared.

\subsection{Electrochemical performance}

From the present research state discussed above, the selected elements, intrinsic drawbacks, and exploited strategies to enhance electrochemical performance for PBAs and $\mathrm{Na}_{\mathrm{x}} \mathrm{MO}_{2}$ can be summarized (Figure 7). Mn and Fe are indispensable elements for PBAs and two important constituents for layered $\mathrm{Na}_{x} \mathrm{MO}_{2}$. Besides some other common elements $(\mathrm{Co}, \mathrm{Ni}, \mathrm{Cu}$, and $\mathrm{Zn})$ used in both PBAs and $\mathrm{Na}_{x} \mathrm{MO}_{2}$, minor quantities of dopant elements ( $\mathrm{Li}, \mathrm{Ti}, \mathrm{Al}, \mathrm{Mg}$, etc.) have been selectively introduced into the framework of layered $\mathrm{Na}_{x} \mathrm{MO}_{2}$ to induce enhanced electrochemical performance.

To cope with the drawbacks of low specific capacity, intrinsic water and vacancies in PBAs crystal structures, PBAs with high crystallinity, high Na content, low vacancies and low coordinate water content are expected to offer enhanced electrochemical performance. The improvement strategies could include suitable composition design, morphology control, quality control, and dehydration treatment together with surface modification. ${ }^{[138-142]}$ It is anticipated 


\section{WILEY-VCH}

that nanostructured PBAs could be prepared with large surface area in academic research. ${ }^{[143-}$

${ }^{144]}$ In the practical battery industry, however, nano-sized materials are easy to absorb moisture, and it is hard to make a suitable electrode coating during the battery manufacturing process. The energy density of reported PBAs could reach $428 \mathrm{Wh} \mathrm{kg}^{-1}$ in a half cell and $136 \mathrm{Wh} \mathrm{kg}^{-1}$ in a full cell. ${ }^{[132,145]}$ Hundreds of cycles could be maintained.

For P2-type layered $\mathrm{Na}_{x} \mathrm{MO}_{2}$, pre-sodiation treatment or sodium salt compensation are sometimes performed to alleviate the sodium deficiency and improve the initial irreversible capacity, but the method may be not very suitable for commercial mass production due to the complicated process and much increased cost. O3-type $\mathrm{Na}_{x} \mathrm{MO}_{2}$, on the other hand, showed the advantages of high energy density and high initial Coulombic efficiency in full cells and has attracted more attention. Micrometer sized products are obtained from the high-temperature calcination process of layered $\mathrm{Na}_{x} \mathrm{MO}_{2}$. Similar strategies are used to alleviate the intrinsic drawbacks (phase transformation, poor cycling stability, and air sensitivity) of layered $\mathrm{Na}_{\mathrm{x}} \mathrm{MO}_{2}$. With rational composition design and structure optimization, introducing minor quantities of cationic substitution is the most utilized and effective way, and it is capable of affording a significant improvement of the overall electrochemical performance, even the air stability. ${ }^{[146]}$ Sacrificial salt compensation and surface modification could effectively endow layered $\mathrm{Na}_{x} \mathrm{MO}_{2}$ materials with improved Coulombic efficiency and longer cycle life. ${ }^{[25,147]}$ The exploration of P- and/or O-type mixed phases, of which several materials with both satisfactory performance and air stability are reported, ${ }^{[14,148]}$ is inspiring a new perspective on the development of layered $\mathrm{Na}_{x} \mathrm{MO}_{2}$. Benefiting from suitable design and optimization, the layered $\mathrm{Na}_{x} \mathrm{MO}_{2}$ can provide an energy density of more than $200 \mathrm{Wh} \mathrm{kg}^{-1}$ in a pouch cell. ${ }^{[117]}$

\subsection{Scaling up potential}

Whether a product is suitable for scaling up depends on its synthetic conditions, yield, and reserves of raw materials. PBAs are normally based on aqueous chemistries and can be 


\section{WILEY-VCH}

synthesized at a low temperature through the co-precipitation method, the hydrothermal/solvothermal method and the electrodeposition method (Figure 7). Among these, the co-precipitation approach, which involves a one-step mixing process in a homogeneous solution, is the most straightforward method to use for scaling up, as proven in LIBs. Hydrothermal/solvothermal methods need a relatively high temperature and high-pressure conditions, so they are hard to scale up. Electrodeposition consumes extra electrical energy and shows little practical merit. PBAs have low solubility product constants, and it is hard to control their growth during mass preparation. Surfactants, chelating agents and excess sodium resources are normally used to control the nucleation and growth speed of PBA nuclei in a particular system. ${ }^{[29,149-151]}$ Low yield is usually found, especially when nanosized PBAs are prepared, which is a big issue for practical manufacturing. Fe- and Mn- based salts are abundant and readily accessible, and they are commonly used raw materials to prepare precursors for PBAs, providing PBAs with scaling up advantages in this regard.

There are three synthetic methods utilized for layered $\mathrm{Na}_{\mathbf{x}} \mathrm{MO}_{2}$ as well, namely, the solidstate method, the sol-gel method, and the co-precipitation method (Figure 7). Similarly, the coprecipitation method is the most suitable method for mass production. Moreover, the battery fabrication and manufacturing equipment used to synthesize transition metal oxides for LIBs can be easily transferred to prepare $\mathrm{Na}_{x} \mathrm{MO}_{2}$ for SIBs. A subsequent high-temperature calcination (above $800^{\circ} \mathrm{C}$ ) is usually needed to obtain the final products, and large yields could be achieved. The solid-state method is reported in most of the published literature where a small amount of sample is needed. It is hard to uniformly mix the raw materials for large-scale solidstate preparation, however, which may result in inhomogeneous products. The sol-gel method requires an additional gel-forming step at elevated temperatures, and does not show advantages for scaling up. The reserves of raw materials differ greatly for different elements of layered $\mathrm{Na}_{x} \mathrm{MO}_{2}$. Abundant Fe- and Mn-based materials deserve extra attention. 


\section{WILEY-VCH}

\subsection{Cost}

In scale-up production, the cost of raw materials and the price to performance ratios particularly need to be taken into consideration. The prices of nickel and cobalt remain high and increasing due to their high demand in LIBs, as shown in Figure 8a. Abundant elements, such as Fe, Mn and $\mathrm{Cu}$, have attractive prices. There are no rare or expensive elements in most PBA materials, which makes them low-cost SIB components. When preparing layered $\mathrm{Na}_{x} \mathrm{MO}_{2}$ with different types of transition metal elements, the usage of expensive elements, such as $\mathrm{Ni}, \mathrm{Co}, \mathrm{Mg}$, and Ti, should be controlled.

The price/performance ratios for selected layered $\mathrm{Na}_{x} \mathrm{MO}_{2}$ and PBAs from the literature were calculated by our group, as shown in Figure $\mathbf{8 b} .^{[92]}$ PBAs generally display a lower price/performance ratio than most of the layered $\mathrm{Na}_{x} \mathrm{MO}_{2}$. Different Fe-PBAs show similar low price/performance ratios, which increase when other elements $(\mathrm{Mn}, \mathrm{Co}, \mathrm{Ni}$, or $\mathrm{Zn}$ ) are introduced into the framework. Although layered $\mathrm{Na}_{x} \mathrm{MO}_{2}$ have much more composition choices, Fe- and Mn-based materials are still the most promising candidates for practical SIBs due to their cost advantages. $\mathrm{Ni}$ - and Co-containing cathodes are more expensive per unit energy density than those composed of $\mathrm{Mn}, \mathrm{Fe}$, and $\mathrm{Cu}$. Fe-based PBAs and O3-type $\mathrm{Na}_{0.9} \mathrm{Fe}_{0.22} \mathrm{Mn}_{0.30} \mathrm{Cu}_{0.48} \mathrm{O}_{2}$ are particularly representative and attractive among these selected materials. Other factors, however, also need to be considered. Inert gas protection and reducing agents are normally needed for Fe-based PBAs to inhibit the oxidation of $\mathrm{Fe}^{2+}$. Similarly, layered $\mathrm{Na}_{x} \mathrm{MO}_{2}$ that are sensitive to moisture and oxygen need inert gas protection for storage and transportation. These requirements would undoubtedly bring increased cost. Additional modification processes and post-treatments, such as carbon coating or dehydration, would increase the manufacturing cost and complexity as well. It is important to find a good balance among all those factors.

\subsection{Environmental friendliness}




\section{WILEY-VCH}

In regards to environmental concerns, the usage of $\mathrm{V}$ - and $\mathrm{Cr}$ - based materials should be limited or inhibited because of their high cost, toxicity, and limited electrochemical activities when choosing materials for layered $\mathrm{Na}_{x} \mathrm{MO}_{2}$. There are no toxic elements involved during the preparation of PBAs. In addition, the post high-temperature treatment exploited to prepare layered $\mathrm{Na}_{x} \mathrm{MO}_{2}$ increases the carbon emissions during mass production. In this regard, PBAs are more environmentally friendly.

The mass production of PBAs requires the consumption of a massive amount of water. Excess sodium sources, surfactants, and chelating agents are used in many preparation processes to endow PBAs with high Na content or good quality along with uniform and controllable morphology. The wastewater formed after centrifugation or filtration, which may contain a certain amount of salt ions and residual additives, is a major issue that needs to be dealt with. Thus, rational materials design and recycling strategies need to be explored for the production of PBAs to minimize the adverse effects on the environment. Ideally, the residual liquid could be recycled and serve as a mother solution for further preparation.

In summary, $\mathrm{PBAs}$ and layered $\mathrm{Na}_{x} \mathrm{MO}_{2}$ demonstrate distinct and unique advantages in terms of electrochemical performance, scale-up potential, cost efficiency, and environmental friendliness for the commercialisation of SIB, as illustrated in Figure 9. Due to their superior cycling stability, PBAs are promising candidates for systems where long lifespan is necessary. Layered $\mathrm{Na}_{x} \mathrm{MO}_{2}$ are suitable for SIBs requiring high energy densities benefiting from their high capacity and high operating voltage. The equipment that is used for transition metal oxides fabrication in LIBs can be easily transferred to the preparation of layered $\mathrm{Na}_{x} \mathrm{MO}_{2}$, making $\mathrm{Na}_{x} \mathrm{MO}_{2}$ easier to scale up than PBAs. The raw materials for PBAs, however, are generally cheaper and more accessible than those of $\mathrm{Na}_{x} \mathrm{MO}_{2}$, endowing PBAs with cost-efficiency advantages. The ratio of expense (raw materials, manufacturing process, modification treatment, battery assembly and storage) to performance needs to be carefully considered when choosing element $(\mathrm{Ni}, \mathrm{Co}$, etc.) that can provide high performance but with a high price for layered 


\section{WILEY-VCH}

$\mathrm{Na}_{x} \mathrm{MO}_{2}$. The usage of toxic elements $(\mathrm{V}, \mathrm{Cr})$ in $\mathrm{Na}_{x} \mathrm{MO}_{2}$ should be limited as much as possible. In addition, the wastewater issue for PBAs makes recycling strategy a necessity regarding environmental concerns. From all the aspects above, Fe- and Mn-based PBAs and O3-type or mixed P-/O-type $\mathrm{Na}_{x} \mathrm{MO}_{2}$ with non-toxic components are welcome candidates for the SIBs system.

\section{Conclusion and perspectives}

The lower cost and safer characteristics make SIBs a compelling system for large energy storage applications compared to LIBs. Substantial academic efforts have been devoted to layered $\mathrm{Na}_{x} \mathrm{MO}_{2}$ and PBAs to study their electrochemical mechanism and find eligible cathode candidates for the SIB system around the world. There are large differences, however, between preparation in the laboratory and a scale-up production at the industry level. Academic and industrial organizations need to cooperate closely and devote extensive efforts to making these promising cathodes ready for practical industrialization.

Opportunities and challenges always coexist. There are still many issues waiting to be solved to promote the final practical usage of SIBs. In the case of PBAs, their intrinsic low gravimetric energy density makes them not ideal for high specific energy applications, but more suitable for systems that emphasize sustainable cycle life. $\mathrm{Fe}\left(\mathrm{M}^{\prime}=\mathrm{Fe}\right)$ is the basic element of PBAs and Fe-based PBAs $\left(\mathrm{M}, \mathrm{M}^{\prime}=\mathrm{Fe}\right)$ have been getting the most attention due to their low cost and good cycling and rate performance. Mn-based PBAs with increased operating voltage also attract attention and have demonstrated their potential. $\mathrm{Ni}$ and $\mathrm{Co}$ were introduced, but the increased cost needs to be taken into consideration. Because PBAs are derived from the liquid chemical synthesis, the intrinsic crystalline water and vacancies in the structure would definitely have an impact on their electrochemical performance. It is important to figure out the reaction mechanisms, including any phase transformation, the water sites within the structure, and the active sodium storage sites during electrochemical cycling, to provide better theoretical 


\section{WILEY-VCH}

guidance. Utmost efforts need to be made to prepare high quality PBAs with low water content, few vacancies, and high Na content. Synthesis approaches with cheap precursors and high yield are desired. PBAs that are micro-sized or have a secondary micro-sized morphology consisting of primary nanostructures are preferable for battery mass production. Increased cost from additional dehydration and optimization processes, wastewater treatment, and recycling strategies need to be considered. Low-cost Fe-based PBAs are still the priority choice.

Layered $\mathrm{Na}_{x} \mathrm{MO}_{2}$ are likely to display higher volumetric energy density compared with PBAs and are more suitable for devices demanding high energy density. Due to the sodium deficiency and the complexity of pre-sodiation for $\mathrm{P} 2$-type $\mathrm{Na}_{x} \mathrm{MO}_{2}$, O3-type materials demonstrate better practical advantages. The capacity deterioration resulting from phase transformation and air sensitivity, however, is still an obstacle to their application. Rational composition and structural design are critical. $\mathrm{Na}_{x} \mathrm{MO}_{2}$ compounds with only one type of transition metal element seldom afford satisfactory performance. Metal (active $\mathrm{Fe}, \mathrm{Co}, \mathrm{Ni}, \mathrm{Mn}$, $\mathrm{Cu}$ or electrochemically inert $\mathrm{Ti}, \mathrm{Mg}$, $\mathrm{Al}$, etc.) substitution or doping into the $\mathrm{Na}_{x} \mathrm{MO}_{2}$ framework, is carried out to take advantage of the synergistic effects of different metal elements and provide great performance improvement. The resulting structural complexity and instability need extra attention, however. Distinct mechanisms that dominate their electrochemical behaviour need to be exploited. Surface modification (carbon, $\mathrm{TiO}_{2}$, and $\mathrm{Al}_{2} \mathrm{O}_{3}$ coating) and sacrificial salt $\left(\mathrm{Na}_{3} \mathrm{P}, \mathrm{NaN}_{3}\right)$ compensation can provide optimized performance as well. Mixed P- and O-phase $\mathrm{Na}_{x} \mathrm{MO}_{2}$ with enhanced performance and air stability deserve further exploration. It is vital to find a balance between the performance and the cost when implementing elemental selection and material modification. Layered $\mathrm{Na}_{x} \mathrm{MO}_{2}$ compounds with adequate cycle life, energy density and air stability are anticipated. High performance O3type or mixed P-/O-type materials with low-cost and non-toxic elements, such as $\mathrm{Fe}, \mathrm{Mn}$ and $\mathrm{Cu}$, are preferable. 


\section{WILEY-VCH}

In regard to polyanionic compound cathode, when it comes to scale-up production, it is hard to get uniform morphology and composition. ${ }^{[58]}$ Compounding with conductive materials and inert gas protection are normally needed. Another type of cathode material, organic compounds, generally show low operating voltages, are easy to dissolve in organic electrolytes, and exhibit inferior cycling stability. The introduction of solid-state electrolyte may be helpful to some extent, but needs lots of extra studies at present. Besides pursing performance and scale-up availability, similar effects regarding cost and environmental protection are needed to be taken into consideration for their potential commercialization as well. Other aspects, including the development of high-voltage electrolytes (salts and solvents), the optimization of electrolyte additives, the choice of binder, the compatibility between electrodes and/or electrolytes, the operating conditions (temperature and time), etc., need synergetic study to guarantee the overall performance and final practicability of PBAs and $\mathrm{Na}_{x} \mathrm{MO}_{2}$ for SIB commercialisation. Although there are many obstacles blocking the way, the successful reports of Novasis Energies, Inc. and Faradion Limited demonstrate the potential of PBAs and $\mathrm{Na}_{x} \mathrm{MO}_{2}$ as SIB cathodes in stationary and large-scale energy storage applications. It can be anticipated that eligible candidates with satisfactory electrochemical performance, scale-up potential, cost-efficiency, and environmental friendliness are emerging, and will eventually contribute to the practical energy storage market in the near future.

\section{Acknowledgements}

This work was supported by an Australian Renewable Energy Agency (ARENA S ${ }^{4}$ project) grant and funds from the National Natural Science Foundation of China (Grant Nos. 51772219 and 51872209) and the Zhejiang Provincial Natural Science Foundation of China (Grant Nos. LZ17E020002, LR17H180001). The authors would like to thank Dr. Tania Silver for her critical revision of the manuscript. All the authors have given approval to the final version of the manuscript. 


\section{WILEY-VCH}

\section{References}

[1] D. Larcher, J.-M. Tarascon, Nat. Chem. 2015, 7, 19.

[2] J. Shankleman, T. Biesheuvel, J. Ryan, D. Merrill, We're Going to Need More Lithium, https://www.bloomberg.com/graphics/2017-lithium-battery-future/, accessed: September, 2017.

[3] S. Yang, F. Zhang, H. Ding, P. He, H. Zhou, Joule 2018, 2, 1648.

[4] C. Vaalma, D. Buchholz, M. Weil, S. Passerini, Nat. Rev. Mater. 2018, 3, 18013.

[5] T. P. Narins, Extr. Ind. Soc. 2017, 4, 321.

[6] Sub-Committee of Experts on the Transport of Dangerous Goods, UN/SCETDG/52/INF.11, 2017.

[7] C. Delmas, Adv. Energy Mater.2018, 8, 1703137.

[8] J.-Y. Hwang, S.-T. Myung, Y.-K. Sun, Chem. Soc. Rev. 2017, 46, 3529.

[9] H. Pan, Y.-S. Hu, L. Chen, Energy Environ. Sci. 2013, 6, 2338.

[10] Y. Zhu, Y. Xu, Y. Liu, C. Luo, C. Wang, Nanoscale 2013, 5, 780.

[11] S. Komaba, C. Takei, T. Nakayama, A. Ogata, N. Yabuuchi, Electrochem. Commun. $2010,12,355$.

[12] K. Xi, S. Chu, X. Zhang, X. Zhang, H. Zhang, H. Xu, J. Bian, T. Fang, S. Guo, P. Liu, M. Chen, H. Zhou, Nano Energy, https://doi.org/10.1016/j.nanoen.2019.104215.

[13] S. M. Kang, J.-H. Park, A. Jin, Y. H. Jung, J. Mun, Y.-E. Sung, ACS Appl. Mater. Interfaces 2018, 10, 3562.

[14] S. Guo, P. Liu, H. Yu, Y. Zhu, M. Chen, M. Ishida, H. Zhou, Angew. Chem. Int. Ed. 2015, 54, 5894.

[15] Y.-P. Deng, Z.-G. Wu, R. Liang, Y. Jiang, D. Luo, A. Yu, Z. Chen, Adv. Funct. Mater. 2019, 29, 1808522.

[16] J.-Y. Hwang, C. S. Yoon, I. Belharouak, Y.-K. Sun, J. Mater. Chem. A 2016, 4, 17952.

[17] Y. Sun, S. Guo, H. Zhou, Adv. Energy Mater. 2019, 9, 1800212. 


\section{WILEY-VCH}

[18] S. Kumakura, Y. Tahara, K. Kubota, K. Chihara, S. Komaba, Angew. Chem. Int. Ed. 2016, 55, 12760.

[19] B. M. De Boisse, D. Carlier, M. Guignard, C. Delmas, J. Electrochem. Soc. 2013, 160, A569.

[20] L. Wang, Y.-G. Sun, L.-L. Hu, J.-Y. Piao, J. Guo, A. Manthiram, J. Ma, A.-M. Cao, J. Mater. Chem. A 2017, 5, 8752.

[21] Q. Liu, Z. Hu, M. Chen, C. Zou, H. Jin, S. Wang, Q. Gu, S. Chou, J. Mater. Chem. A 2019, 7, 9215 .

[22] X. Wang, M. Tamaru, M. Okubo, A. Yamada, J. Phys. Chem. C 2013, 117, 15545.

[23] T.-Y. Yu, J.-Y. Hwang, D. Aurbach, Y.-K. Sun, ACS Appl. Mater. Interfaces 2017, 9, 44534.

[24] C.-Y. Yu, J.-S. Park, H.-G. Jung, K.-Y. Chung, D. Aurbach, Y.-K. Sun, S.-T. Myung, Energy Environ. Sci. 2015, 8, 2019.

[25] Y. Park, J. Choi, J. Jo, C.-H. Jo, J. Kim, S.-T. Myung, Adv. Funct. Mater. 2019, 29, 1901912.

[26] X. Zheng, P. Li, H. Zhu, K. Rui, G. Zhao, J. Shu, X. Xu, W. Sun, S. X. Dou, Energy Storage Mater. 2018, 15, 257.

[27] J. Song, L. Wang, Y. Lu, J. Liu, B. Guo, P. Xiao, J.-J Lee, X.-Q. Yang, G. Henkelman, J. Goodenough, J. Am. Chem. Soc. 2015, 137, 2658.

[28] Y. Yue, A. J. Binder, B. Guo, Z. Zhang, Z. A. Qiao, C. Tian, S. Dai, Angew. Chem. Int. Ed. 2014, 53, 3134 .

[29] X. Jiang, H. Liu, J. Song, C. Yin, H. Xu, J. Mater. Chem. A 2016, 4, 16205.

[30] S. Yu, Y. Li, Y. Lu, B. Xu, Q. Wang, M. Yan, Y. Jiang, J. Power Sources 2015, 275, 45.

[31] W. Ren, Z. Zhu, M. Qin, S. Chen, X. Yao, Q. Li, X. Xu, Q. Wei, L. Mai, C. Zhao, Adv. Funct. Mater. 2019, 29, 1806405. 


\section{WILEY-VCH}

[32] F. Feng, S. Chen, X. Z. Liao, Z. F. Ma, Small Methods 2019, 3, 1800259.

[33] Q. Ni, Y. Bai, F. Wu, C. Wu, Adv. Sci. 2017, 4, 1600275.

[34] P. Barpanda, G. Oyama, S.-i. Nishimura, S.-C. Chung, A. Yamada, Nat. Commun. 2014, $5,4358$.

[35] Y. Fang, L. Xiao, X. Ai, Y. Cao, H. Yang, Adv. Mater. 2015, 27, 5895.

[36] C. Chen, T. Li, H. Tian, Y. Zou, J. Sun, J. Mater. Chem. A 2019, 7, 18451.

[37] M. Bianchini, P. Xiao, Y. Wang, G. Ceder, Adv. Energy Mater. 2017, 7, 1700514.

[38] P. Barpanda, G. Liu, C. D. Ling, M. Tamaru, M. Avdeev, S.-C. Chung, Y. Yamada, A. Yamada, Chem. Mater. 2013, 25, 3480.

[39] P. Singh, K. Shiva, H. Celio, J. B. Goodenough, Energy Environ. Sci. 2015, 8, 3000.

[40] S. Li, J. Guo, Z. Ye, X. Zhao, S. Wu, J.-X. Mi, C.-Z. Wang, Z. Gong, M. J. McDonald, Z. Zhu, ACS Appl. Mater. Interfaces 2016, 8, 17233.

[41] Y. U. Park, D. H. Seo, H. Kim, J. Kim, S. Lee, B. Kim, K. Kang, Adv. Funct. Mater. 2014, 24, 4603.

[42] M. Chen, W. Hua, J. Xiao, D. Cortie, W. Chen, E. Wang, Z. Hu, Q. Gu, X. Wang, S. Indris, Nat. Commun. 2019, 10, 1480.

[43] E. Wang, M. Chen, X. Liu, Y. Liu, H. Guo, Z. Wu, W. Xiang, B. Zhong, X. Guo, S. Chou, Small Methods 2019, 3, 1800169.

[44] Y.-U. Park, D.-H. Seo, H.-S. Kwon, B. Kim, J. Kim, H. Kim, I. Kim, H.-I. Yoo, K. Kang, J. Am. Chem. Soc. 2013, 135, 13870.

[45] M. Chen, L. Chen, Z. Hu, Q. Liu, B. Zhang, Y. Hu, Q. Gu, J. L. Wang, L. Z. Wang, X. Guo, Adv. Mater. 2017, 29, 1605535.

[46] Y. Liu, N. Zhang, F. Wang, X. Liu, L. Jiao, L.-Z. Fan, Adv. Funct. Mater. 2018, 28, 1801917.

[47] P. Barpanda, L. Lander, S. i. Nishimura, A. Yamada, Adv. Energy Mater. 2018, 8, 1703055. 


\section{WILEY-VCH}

[48] Q. Zhao, Y. Lu, J. Chen, Adv. Energy Mater. 2017, 7, 1601792.

[49] S. Wang, L. Wang, Z. Zhu, Z. Hu, Q. Zhao, J. Chen, Angew. Chem. Int. Ed. 2014, 53, 5892.

[50] Y. Park, D. S. Shin, S. H. Woo, N. S. Choi, K. H. Shin, S. M. Oh, K. T. Lee, S. Y. Hong, Adv. Mater. 2012, 24, 3562.

[51] W. Deng, X. Liang, X. Wu, J. Qian, Y. Cao, X. Ai, J. Feng, H. Yang, Sci. Rep. 2013, 3, 2671.

[52] W. Luo, M. Allen, V. Raju, X. Ji, Adv. Energy Mater. 2014, 4, 1400554.

[53] Y. Wang, Y. Ding, L. Pan, Y. Shi, Z. Yue, Y. Shi, G. Yu, Nano Lett. 2016, 16, 3329.

[54] M. Zhou, W. Li, T. Gu, K. Wang, S. Cheng, K. Jiang, Chem. Commun. 2015, 51, 14354.

[55] Z. Song, Y. Qian, T. Zhang, M. Otani, H. Zhou, Adv. Sci. 2015, 2, 1500124.

[56] Z. Song, H. Zhou, Energy Environ. Sci. 2013, 6, 2280.

[57] M. Lee, J. Hong, J. Lopez, Y. Sun, D. Feng, K. Lim, W. C. Chueh, M. F. Toney, Y. Cui, Z. Bao, Nat. Energy 2017, 2, 861.

[58] M. Chen, Q. Liu, S. W. Wang, E. Wang, X. Guo, S. L. Chou, Adv. Energy Mater. 2019, 9, 1803609.

[59] K. Chayambuka, G. Mulder, D. L. Danilov, P. H. Notten, Adv. Energy Mater. 2018, 8, 1800079.

[60] K. Kubota, M. Dahbi, T. Hosaka, S. Kumakura, S. Komaba, Chem. Rec. 2018, 18, 459.

[61] P. K. Nayak, L. Yang, W. Brehm, P. Adelhelm, Angew. Chem. Int. Ed. 2018, 57, 102.

[62] J. Qian, C. Wu, Y. Cao, Z. Ma, Y. Huang, X. Ai, H. Yang, Adv. Energy Mater. 2018, 8, 1702619.

[63] P. F. Wang, Y. You, Y. X. Yin, Y. G. Guo, Adv. Energy Mater. 2018, 8, 1701912.

[64] H. Su, S. Jaffer, H. Yu, Energy Storage Mater. 2016, 5, 116.

[65] L. P. Wang, L. Yu, X. Wang, M. Srinivasan, Z. J. Xu, J. Mater. Chem. A 2015, 3, 9353. 


\section{WILEY-VCH}

[66] J. Deng, W. B. Luo, S. L. Chou, H. K. Liu, S. X. Dou, Adv. Energy Mater. 2018, 8, 1701428.

[67] S. Mariyappan, Q. Wang, J. M. Tarascon, J. Electrochem. Soc. 2018, 165, A3714.

[68] B. Wang, Y. Han, X. Wang, N. Bahlawane, H. Pan, M. Yan, Y. Jiang, iScience 2018, 3, 110.

[69] Y. B. Niu, Y. X. Yin, Y. G. Guo, Small 2019, 1900233.

[70] Y. Fang, Z. Chen, L. Xiao, X. Ai, Y. Cao, H. Yang, Small 2018, 14, 1703116.

[71] X. Xiang, K. Zhang, J. Chen, Adv. Mater. 2015, 27, 5343.

[72] Y. Li, Y. Lu, C. Zhao, Y.-S. Hu, M.-M. Titirici, H. Li, X. Huang, L. Chen, Energy Storage Mater. 2017, 7, 130.

[73] F. Ma, Q. Li, T. Wang, H. Zhang, G. Wu, Sci. Bull. 2017, 62, 358.

[74] S. W. Kim, D. H. Seo, X. Ma, G. Ceder, K. Kang, Adv. Energy Mater. 2012, 2, 710.

[75] W. J. Li, C. Han, G. Cheng, S. L. Chou, H. K. Liu, S. X. Dou, Small 2019, 1900470.

[76] C. Fang, Y. Huang, W. Zhang, J. Han, Z. Deng, Y. Cao, H. Yang, Adv. Energy Mater. 2016, 6, 1501727.

[77] Q. Liu, Z. Hu, M. Chen, C. Zou, H. Jin, S. Wang, S. L. Chou, S. X. Dou, Small 2019, 1805381.

[78] C. Zhao, Y. Lu, L. Chen, Y.-S. Hu, Nano Res. 2019, 12, 2018.

[79] S. Guo, J. Yi, Y. Sun, H. Zhou, Energy Environ. Sci. 2016, 9, 2978.

[80] N. Yabuuchi, K. Kubota, M. Dahbi, S. Komaba, Chem. Rev. 2014, 114, 11636.

[81] Y. You, A. Manthiram, Adv. Energy Mater. 2018, 8, 1701785.

[82] R. J. Clément, P. G. Bruce, C. P. Grey, J. Electrochem. Soc. 2015, 162, A2589.

[83] W. Ren, Z. Zhu, Q. An, L. Mai, Small 2017, 13, 1604181.

[84] N. Ortiz-Vitoriano, N. E. Drewett, E. Gonzalo, T. Rojo, Energy Environ. Sci. 2017, 10, 1051.

[85] K. Kubota, S. Komaba, J. Electrochem. Soc. 2015, 162, A2538. 


\section{WILEY-VCH}

[86] N. Yabuuchi, S. Komaba, Sci. Technol. Adv. Mater. 2014, 15, 043501.

[87] V. Palomares, P. Serras, I. Villaluenga, K. B. Hueso, J. Carretero-González, T. Rojo, Energy Environ. Sci. 2012, 5, 5884.

[88] D. Kundu, E. Talaie, V. Duffort, L. F. Nazar, Angew. Chem. Int. Ed. 2015, 54, 3431.

[89] C. Liu, Z. G. Neale, G. Cao, Mater. Today 2016, 19, 109.

[90] J. Zhang, W. Wang, W. Wang, S. Wang, B. Li, ACS Appl. Mater. Interfaces 2019, 11, 22051.

[91] Y. Xu, S. Zheng, H. Tang, X. Guo, H. Xue, H. Pang, Energy Storage Mater. 2017, 9, 11.

[92] W. J. Li, C. Han, W. Wang, F. Gebert, S. L. Chou, H. K. Liu, X. Zhang, S. X. Dou, Adv. Energy Mater. 2017, 7, 1700274.

[93] M. H. Han, E. Gonzalo, G. Singh, T. Rojo, Energy Environ. Sci. 2015, 8, 81.

[94] A. Paolella, C. Faure, V. Timoshevskii, S. Marras, G. Bertoni, A. Guerfi, A. Vijh, M. Armand, K. Zaghib, J. Mater. Chem. A 2017, 5, 18919.

[95] Q. Liu, Z. Hu, M. Chen, Q. Gu, Y. Dou, Z. Sun, S. Chou, S. X. Dou, ACS Appl. Mater. Interfaces 2017, 9, 3644.

[96] S. Xu, Y. Wang, L. Ben, Y. Lyu, N. Song, Z. Yang, Y. Li, L. Mu, H. T. Yang, L. Gu, Adv. Energy Mater. 2015, 5, 1501156.

[97] S. Guo, H. Yu, D. Liu, W. Tian, X. Liu, N. Hanada, M. Ishida, H. Zhou, Chem. Commun. 2014, 50, 7998 .

[98] C. Delmas, J.-J. Braconnier, C. Fouassier, P. Hagenmuller, Solid State Ionics 1981, 3, 165.

[99] X. Zhang, K. Jiang, S. Guo, X. Mu, X. Zhang, P. He, M. Han, H. Zhou, Chem. Commun. 2018, 54, 12167.

[100] N.-A. Nguyen, K. Kim, K. H. Choi, H. Jeon, K. Lee, M.-H. Ryou, Y. M. Lee, J. Electrochem. Soc. 2017, 164, A6308. 


\section{WILEY-VCH}

[101] J. Paulsen, J. Dahn, Solid State Ionics 1999, 126, 3.

[102] N. Yabuuchi, H. Yoshida, S. Komaba, Electrochemistry 2012, 80, 716.

[103] V. Duffort, E. Talaie, R. Black, L. F. Nazar, Chem. Mater. 2015, 27, 2515.

[104] J.-Y. Hwang, S.-T. Myung, Y.-K. Sun, J. Phys. Chem. C 2018, 122, 13500.

[105] X. Ma, H. Chen, G. Ceder, J. Electrochem. Soc. 2011, 158, A1307.

[106] P. Vassilaras, X. Ma, X. Li, G. Ceder, J. Electrochem. Soc. 2013, 160, A207.

[107] D. Hamani, M. Ati, J.-M. Tarascon, P. Rozier, Electrochem. Commun. 2011, 13, 938.

[108] K. Kubota, T. Asari, H. Yoshida, N. Yaabuuchi, H. Shiiba, M. Nakayama, S. Komaba, Adv. Funct. Mater. 2016, 26, 6047.

[109] H. Yoshida, N. Yabuuchi, S. Komaba, Electrochem. Commun. 2013, 34, 60.

[110] N. Yabuuchi, M. Kajiyama, J. Iwatate, H. Nishikawa, S. Hitomi, R. Okuyama, R. Usui, Y. Yamada, S. Komaba, Nat. Mater. 2012, 11, 512.

[111] E. Lee, J. Lu, Y. Ren, X. Luo, X. Zhang, J. Wen, D. Miller, A. DeWahl, S. Hackney, B. Key, Adv. Energy Mater. 2014, 4, 1400458.

[112] M. Keller, D. Buchholz, S. Passerini, Adv. Energy Mater. 2016, 6, 1501555.

[113] G.-L. Xu, R. Amine, Y.-F. Xu, J. Liu, J. Gim, T. Ma, Y. Ren, C.-J. Sun, Y. Liu, X. Zhang, Energy Environ. Sci. 2017, 10, 1677.

[114] G. Gao, D. Tie, H. Ma, H. Yu, S. Shi, B. Wang, S. Xu, L. Wang, Y. Zhao, J. Mater. Chem. A 2018, 6, 6675.

[115] J. Chen, L. Li, L. Wu, Q. Yao, H. Yang, Z. Liu, L. Xia, Z. Chen, J. Duan, S. Zhong, J. Power Sources 2018, 406, 110.

[116] Y.-N. Zhou, P.-F. Wang, Y.-B. Niu, Q. Li, X. Yu, Y.-X. Yin, S. Xu, Y.-G. Guo, Nano Energy 2019, 55, 143.

[117] L. Mu, S. Xu, Y. Li, Y. S. Hu, H. Li, L. Chen, X. Huang, Adv. Mater. 2015, 27, 6928.

[118] S.-M. Oh, S.-T. Myung, J.-Y. Hwang, B. Scrosati, K. Amine, Y.-K. Sun, Chem. Mater. 2014, 26, 6165 . 


\section{WILEY-VCH}

[119] J. H. Jo, J. U. Choi, A. Konarov, H. Yashiro, S. Yuan, L. Shi, Y. K. Sun, S. T. Myung, Adv. Funct. Mater. 2018, 28, 1705968.

[120] J. M. De Ilarduya, L. Otaegui, J. M. L. del Amo, M. Armand, G. Singh, J. Power Sources 2017, 337, 197.

[121] E. De La Llave, V. Borgel, K.-J. Park, J.-Y. Hwang, Y.-K. Sun, P. Hartmann, F.-F. Chesneau, D. Aurbach, ACS Appl. Mater. Interfaces 2016, 8, 1867.

[122] L. Cailloce, A battery Revolution in Motion, https://news.cnrs.fr/articles/a-batteryrevolution-in-motion, accessed: November, 2015.

[123] K. Smith, J. Treacher, D. Ledwoch, P. Adamson, E. Kendrick, ECS Trans. 2017, 75, 13.

[124] Y. S. Hu, S. Komaba, M. Forsyth, C. Johnson, T. Rojo, Small Methods 2019, 3, 1900184.

[125] M. Wan, Y. Tang, L. Wang, X. Xiang, X. Li, K. Chen, L. Xue, W. Zhang, Y. Huang, J. Power Sources 2016, 329, 290.

[126] X. Bie, K. Kubota, T. Hosaka, K. Chihara, S. Komaba, J. Power Sources 2018, 378, 322.

[127] H.-W. Lee, R. Y. Wang, M. Pasta, S. W. Lee, N. Liu, Y. Cui, Nat. Commun. 2014, 5, 5280.

[128] J. Peng, J. Wang, H. Yi, W. Hu, Y. Yu, J. Yin, Y. Shen, Y. Liu, J. Luo, Y. Xu, Adv. Energy Mater. 2018, 8, 1702856.

[129] Y. Jiang, S. Yu, B. Wang, Y. Li, W. Sun, Y. Lu, M. Yan, B. Song, S. Dou, Adv. Funct. Mater. 2016, 26, 5315.

[130] Y. You, X.-L. Wu, Y.-X. Yin, Y.-G. Guo, Energy Environ. Sci. 2014, 7, 1643.

[131] L. Wang, J. Song, R. Qiao, L. A. Wray, M. A. Hossain, Y.-D. Chuang, W. Yang, Y. Lu, D. Evans, J.-J. Lee, J. Am. Chem. Soc. 2015, 137, 2548.

[132] W.-J. Li, S.-L. Chou, J.-Z. Wang, J.-L. Wang, Q.-F. Gu, H.-K. Liu, S.-X. Dou, Nano Energy 2015, 13, 200. 


\section{WILEY-VCH}

[133] W. Li, C. Han, Q. Xia, K. Zhang, S. Chou, Y. M. Kang, J. Wang, H. K. Liu, S. X. Dou, Small Methods 2018, 2, 1700346.

[134] Y. You, H. R. Yao, S. Xin, Y. X. Yin, T. T. Zuo, C. P. Yang, Y. G. Guo, Y. Cui, L. J.

Wan, J. B. Goodenough, Adv. Mater. 2016, 28, 7243.

[135] J. Qian, M. Zhou, Y. Cao, X. Ai, H. Yang, Adv. Energy Mater. 2012, 2, 410.

[136] A. Bauer, J. Song, S. Vail, W. Pan, J. Barker, Y. Lu, Adv. Energy Mater. 2018, 8, 1702869.

[137] P. Ge, S. Li, H. Shuai, W. Xu, Y. Tian, L. Yang, G. Zou, H. Hou, X. Ji, Adv. Mater. 2019, 31, 1806092.

[138] D. S. Kim, M. B. Zakaria, M.-S. Park, A. Alowasheeir, S. M. Alshehri, Y. Yamauchi, H. Kim, Electrochim. Acta 2017, 240, 300.

[139] M. Okubo, C. H. Li, D. R. Talham, Chem. Commun. 2014, 50, 1353.

[140] X. Wu, W. Deng, J. Qian, Y. Cao, X. Ai, H. Yang, J. Mater. Chem. A 2013, 1, 10130.

[141] Y. Qiao, G. Wei, J. Cui, M. Zhang, X. Cheng, D. He, S. Li, Y. Liu, Chem. Commun. 2019, 55, 549 .

[142] B. Xie, P. Zuo, L. Wang, J. Wang, H. Huo, M. He, J. Shu, H. Li, S. Lou, G. Yin, Nano Energy 2019, 61, 201.

[143] Y. Liu, D. He, R. Han, G. Wei, Y. Qiao, Chem. Commun. 2017, 53, 5569.

[144] P. Nie, J. Yuan, J. Wang, Z. Le, G. Xu, L. Hao, G. Pang, Y. Wu, H. Dou, X. Yan, ACS Appl. Mater. Interfaces 2017, 9, 20306.

[145] H. Ye, Y. Wang, F. Zhao, W. Huang, N. Han, J. Zhou, M. Zeng, Y. Li, J. Mater. Chem. A 2016, 4, 1754.

[146] D. Buchholz, L. G. Chagas, C. Vaalma, L. Wu, S. Passerini, J. Mater. Chem. A 2014, 2, 13415.

[147] S. Guo, Q. Li, P. Liu, M. Chen, H. Zhou, Nat. Commun. 2017, 8, 135. 


\section{WILEY-VCH}

[148] Z.-Y. Li, J. Zhang, R. Gao, H. Zhang, L. Zheng, Z. Hu, X. Liu, J. Phys. Chem. C 2016, $120,9007$.

[149] W.-J. Li, S.-L. Chou, J.-Z. Wang, Y.-M. Kang, J.-L. Wang, Y. Liu, Q.-F. Gu, H.-K. Liu, S.-X. Dou, Chem. Mater. 2015, 27, 1997.

[150] X. Wu, C. Wu, C. Wei, L. Hu, J. Qian, Y. Cao, X. Ai, J. Wang, H. Yang, ACS Appl. Mater. Interfaces 2016, 8, 5393.

[151] Y. Huang, M. Xie, J. Zhang, Z. Wang, Y. Jiang, G. Xiao, S. Li, L. Li, F. Wu, R. Chen, Nano Energy 2017, 39, 273.

[152] K. Turcheniuk, D. Bondarev, V. Singhal, G. Yushin, Nature, 2018, 559, 467.
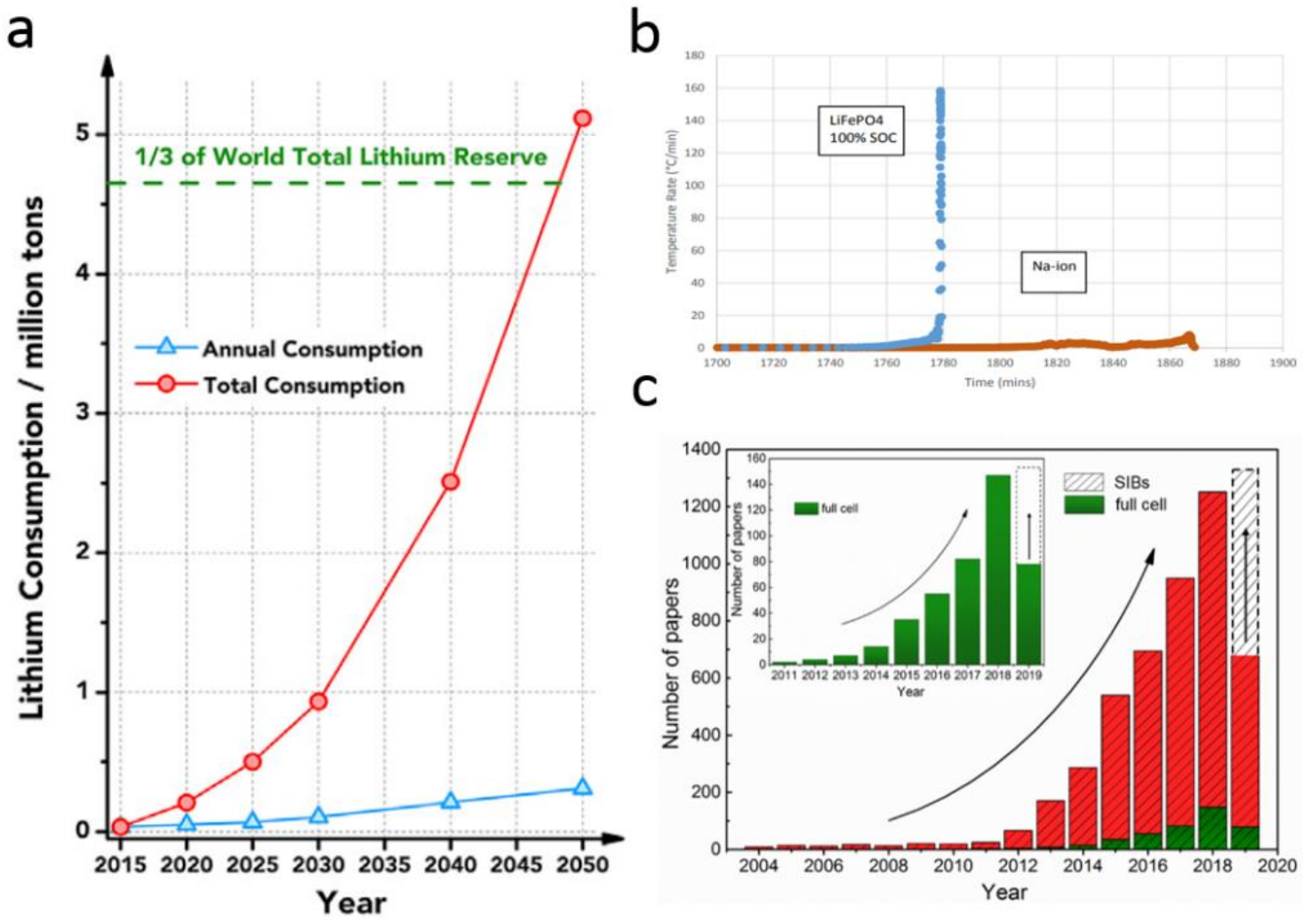

Figure 1. (a) Annual and total lithium consumption in 2015-2050 under the assumption that only the demand from electric vehicles will increase while other uses remain constant. Reproduced with permission. ${ }^{[3]}$ Copyright 2018, Cell Press. (b) Accelerating rate calorimetry results for a $100 \%$ SOC $\mathrm{LiFePO}_{4}$ battery compared with 0\% SOC SIBs. Reproduced with 


\section{WILEY-VCH}

permission. ${ }^{[6]}$ Copyright 2017, UN/SCETDG. (c) Histogram showing the number of published papers on SIBs and full-cell of SIBs (inset) annually (data are summarized from the Web of Science on Sep 2019).

a

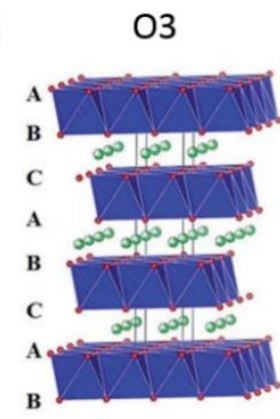

b

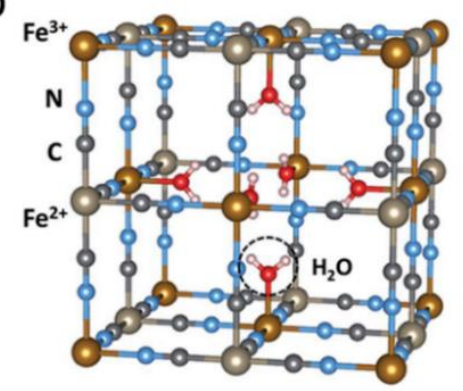

P2

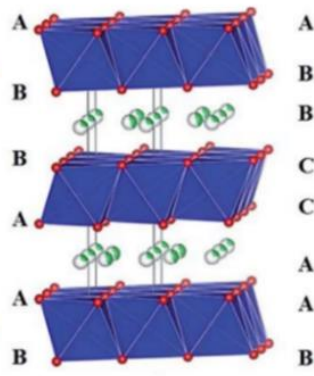

P3

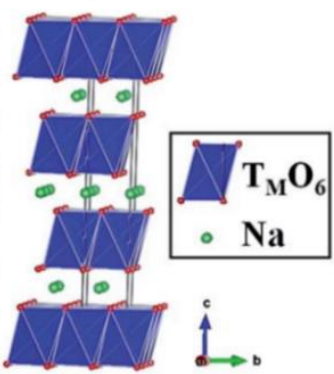

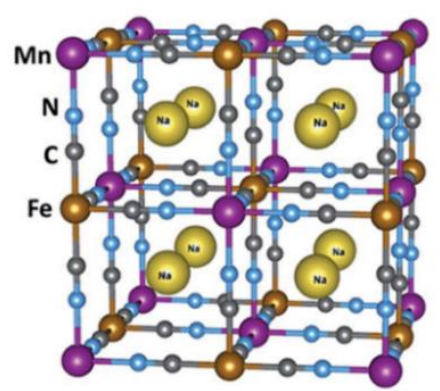

Figure 2. Schematic illustrations of the crystal structures of (a) layered $\mathrm{Na}_{x} \mathrm{MO}_{2}$ and (b) $\mathrm{PB}$ $\left(\mathrm{Fe}_{4}\left[\mathrm{Fe}(\mathrm{CN})_{6}\right]_{3} \cdot n \mathrm{H}_{2} \mathrm{O}\right)$ and typical PBAs $\left(\mathrm{Na}_{x} \mathrm{MnFe}(\mathrm{CN})_{6}\right)$. Reproduced with permission. ${ }^{[93]}$ Copyright 2015, Royal Society of Chemistry. Reproduced with permission. ${ }^{[94]}$ Copyright 2017, Royal Society of Chemistry. 

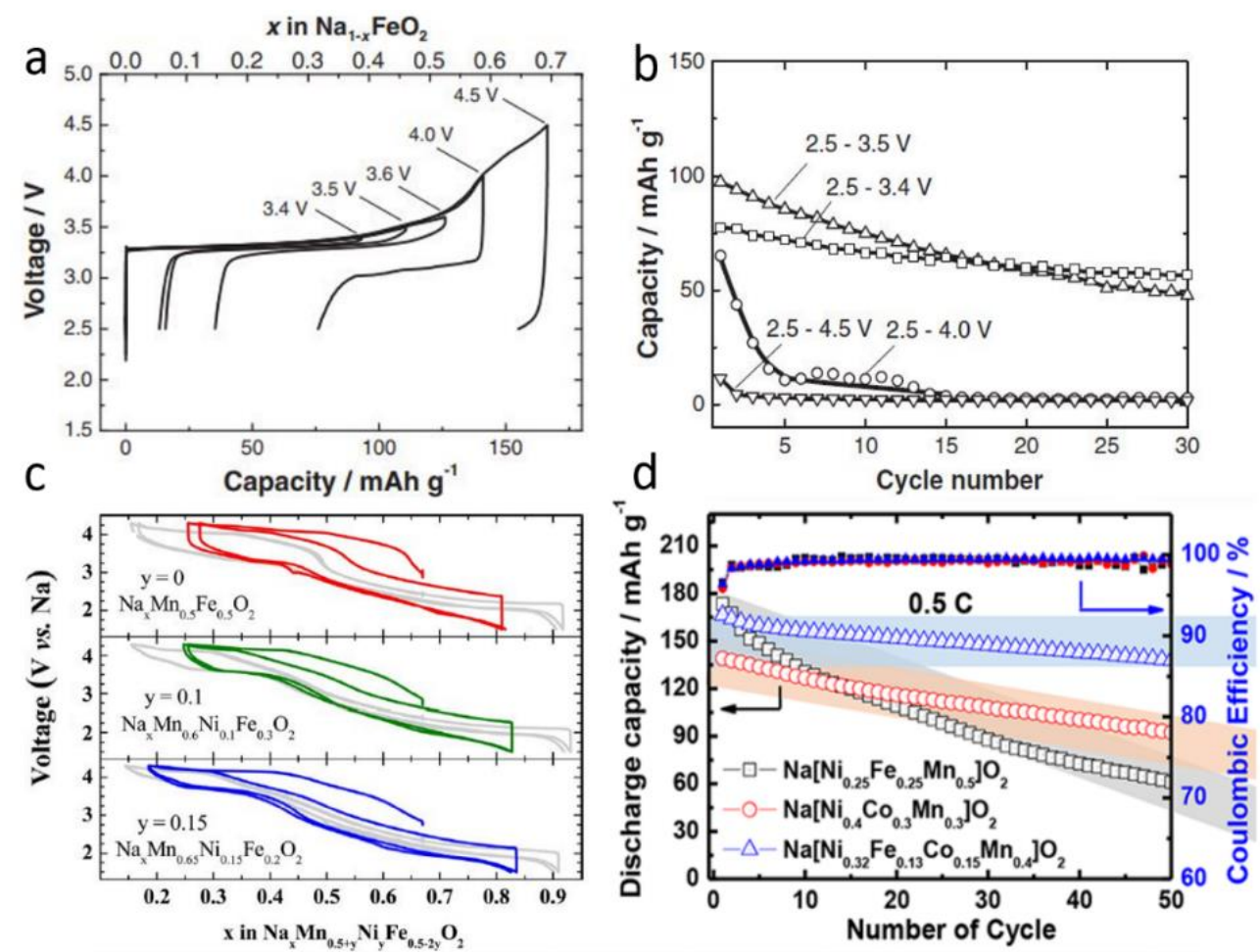

$\mathrm{e}$

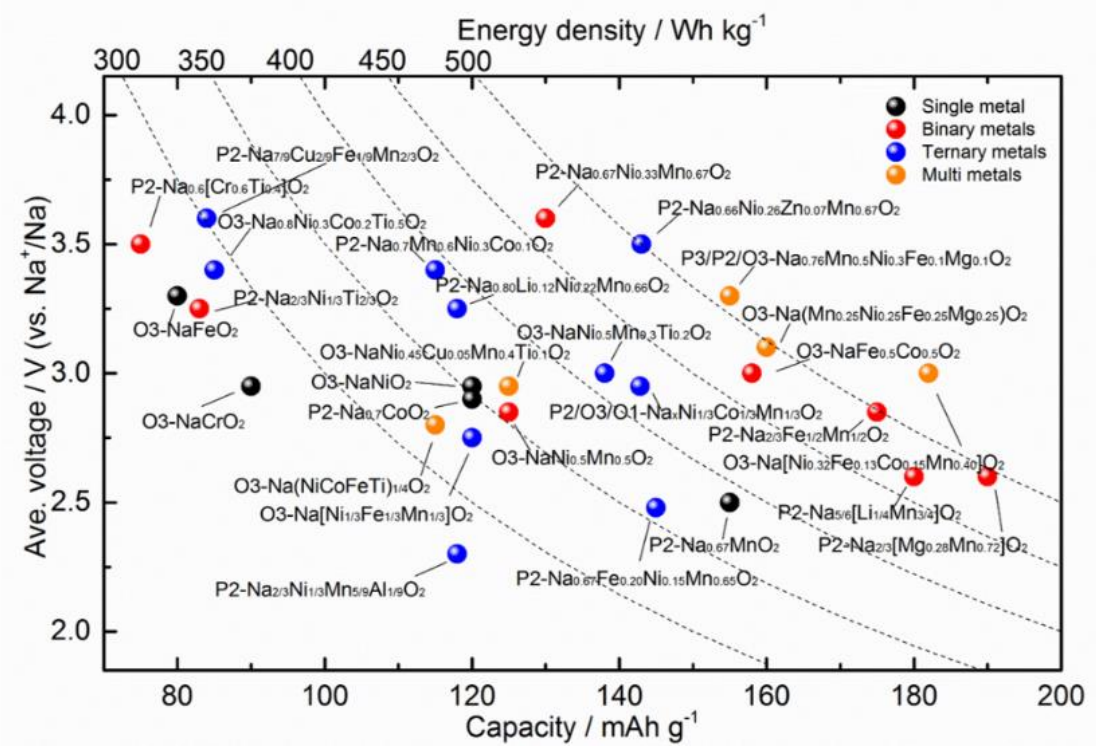

Figure 3. (a) Initial charge/discharge profiles and (b) cycling performance of $\mathrm{NaFeO}_{2}$ cells with different cut-off voltages at $12 \mathrm{~mA} \mathrm{~g}^{-1}$. Reproduced with permission. ${ }^{[102]}$ Copyright 2012 , The Electrochemical Society of Japan. (c) Charge/discharge curves of $\mathrm{Na}_{0.67}\left[\mathrm{Mn}_{0.5+y} \mathrm{Ni}_{y} \mathrm{Fe}_{0.5-2 y}\right] \mathrm{O}_{2}$ $(y=0,0.1$, and 0.15$)$ with profiles of air-protected electrodes shown in grey for comparison. Reproduced with permission. ${ }^{[103]}$ Copyright 2015, American Chemical Society. (d) Cycling performance of $\quad \mathrm{Na}\left[\mathrm{Ni}_{0.25} \mathrm{Fe}_{0.25} \mathrm{Mn}_{0.5}\right] \mathrm{O}_{2}, \quad \mathrm{Na}\left[\mathrm{Ni}_{0.4} \mathrm{Co}_{0.3} \mathrm{Mn}_{0.3}\right] \mathrm{O}_{2}, \quad$ and $\mathrm{Na}\left[\mathrm{Ni}_{0.32} \mathrm{Fe}_{0.13} \mathrm{Co}_{0.15} \mathrm{Mn}_{0.40}\right] \mathrm{O}_{2}$ cathodes at $75 \mathrm{~mA} \mathrm{~g}^{-1}$ in the voltage range of $1.5-4.3 \mathrm{~V}$. 


\section{WILEY-VCH}

Reproduced with permission. Reproduced with permission. ${ }^{[104]}$ Copyright 2018, American Chemical Society. (e) Diagram of capacity and voltage with energy density curves superimposed for $\mathrm{Na}_{\mathrm{x}} \mathrm{MO}_{2}$ with different numbers of transition metals in half-cell systems.
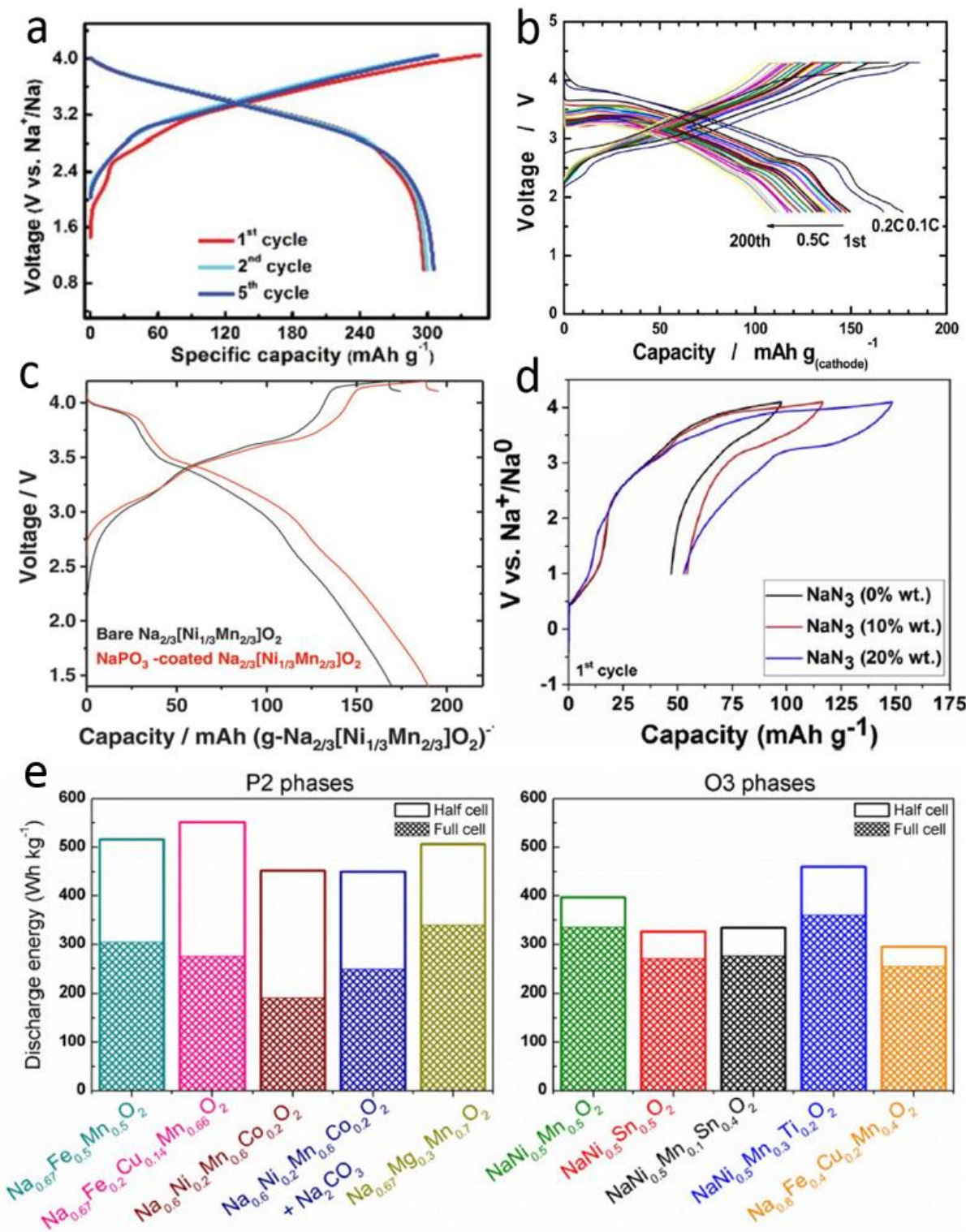

Figure 4. (a) Charge and discharge curves at different cycles of and O3-

$\mathrm{Na}_{0.9}\left[\mathrm{Cu}_{0.22} \mathrm{Fe}_{0.30} \mathrm{Mn}_{0.48}\right] \mathrm{O}_{2} / /$ hard carbon full cell cycled at the $0.5 \mathrm{C}$ rate in the voltage range of 1.0-4.05 V. Reproduced with permission. ${ }^{[117]}$ Copyright 2015, Wiley-VCH. (b) Charge/discharge curves from continuous cycling data for a Na$\left[\mathrm{Li}_{0.05}\left(\mathrm{Ni}_{0.25} \mathrm{Fe}_{0.25} \mathrm{Mn}_{0.5}\right)_{0.95}\right] \mathrm{O}_{2} / /$ hard carbon full cell measured at $0.1,0.2$, and $0.5 \mathrm{C}$. Reproduced with permission. ${ }^{[18]}$ Copyright 2014, American Chemical Society. (c) Initial 


\section{WILEY-VCH}

charge and discharge curves of bare and $\mathrm{NaPO}_{3}$-coated $\mathrm{Na}_{2 / 3}\left[\mathrm{Ni}_{1 / 3} \mathrm{Mn}_{2 / 3}\right] \mathrm{O}_{2} / /$ hard carbon full cells at $0.2 \mathrm{C}$ from 1.4 to $4.2 \mathrm{~V}$. Reproduced with permission. ${ }^{[19]}$ Copyright 2018, Wiley-VCH. (d) Galvanostatic cycles of hard carbon// $/ \mathrm{Na}_{0.67}\left[\mathrm{Fe}_{0.5} \mathrm{Mn}_{0.5}\right] \mathrm{O}_{2}$ full cells with $0 \%$ wt., $10 \%$ wt. and $20 \%$ wt. $\mathrm{NaN}_{3}$ in the voltage range of 1.0-4.1 V. Reproduced with permission. ${ }^{[120]}$ Copyright 2017, Elsevier. (e) Bar chart comparing the specific energies of selected layered $\mathrm{Na}_{\mathrm{x}} \mathrm{MO}_{2}$ in half-cell and full-cell configurations. The energies were calculated based on the cathode weight. Reproduced under the terms and conditions of the Creative Commons CC. ${ }^{[67]}$ Copyright 2018, The Authors. Published by The Electrochemial Society.
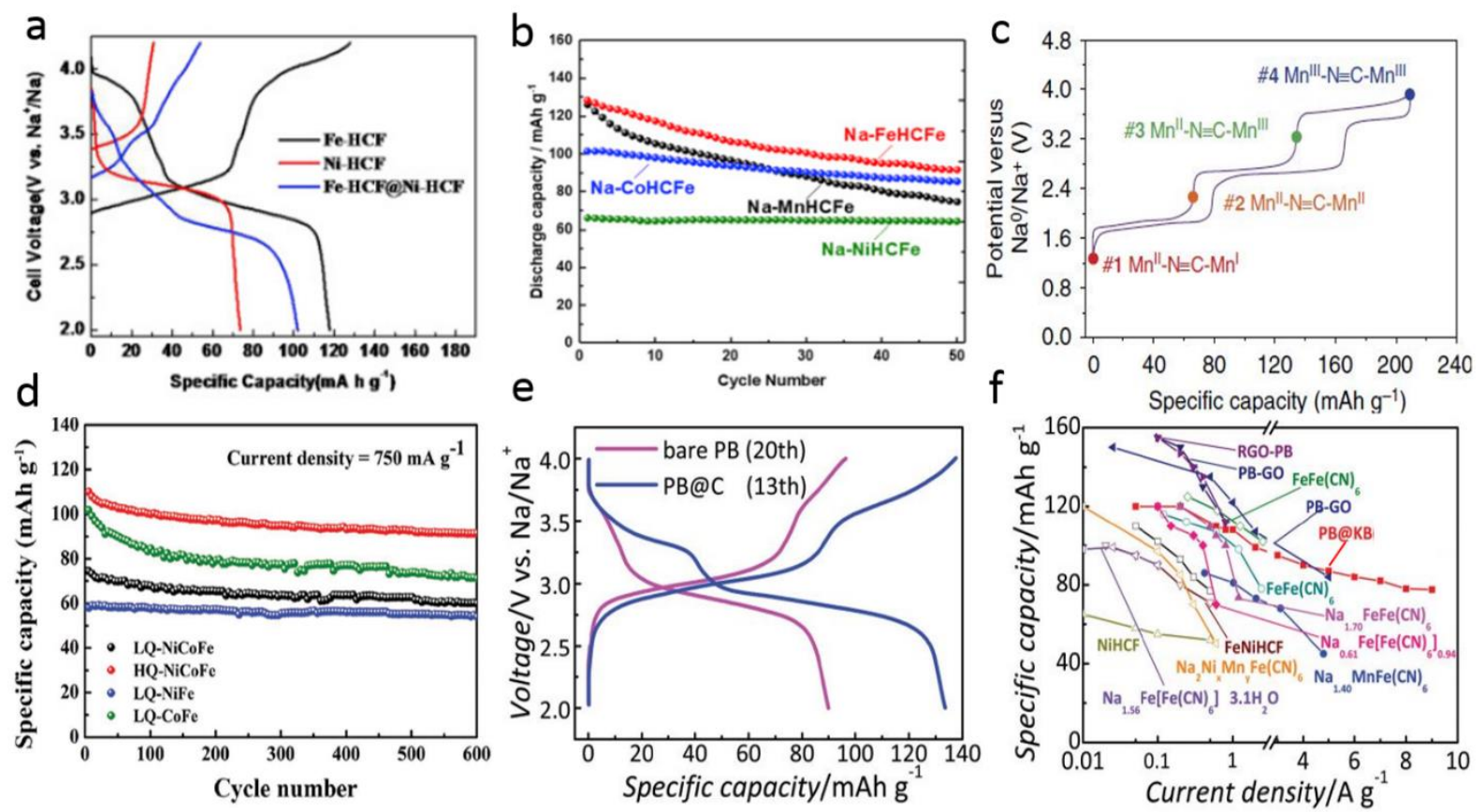

Figure 5. (a) Charge-discharge curves of Fe-HCF, Ni-HCF, and core-shell Fe-HCF@ Ni-HCF at a current density of $25 \mathrm{~mA} \mathrm{~g}^{-1}$. Reproduced with permission. ${ }^{[125]}$ Copyright 2016, Elsevier. (b) Cycling performance of Na-MnHCFe, Na-FeHCFe, Na-CoHCFe, and $\mathrm{Na}-\mathrm{NiHCFe}$ at a current density of $30 \mathrm{~mA} \mathrm{~g}^{-1}$ in the voltage range of 2.0-4.2 V. Reproduced with permission. ${ }^{[126]}$ Copyright 2018, Elsevier. (c) Galvanostatic charge/discharge curves at $0.2 \mathrm{C}$ of $\mathrm{Na}_{2} \mathrm{Mn}^{\mathrm{II}}\left[\mathrm{Mn}^{\mathrm{II}}(\mathrm{CN})_{6}\right.$. Reproduced with permission. ${ }^{[127]}$ Copyright 2014 , Nature Publishing Group. (d) Long-cycling performance at a current density of $750 \mathrm{~mA} \mathrm{~g}^{-1}$ of LQ-NiFe, LQ-CoFe, LQ-NiCoFe, and HQ-NiCoFe. Reproduced with permission. ${ }^{[128]}$ Copyright 2018, Wiley-VCH. 


\section{WILEY-VCH}

(e) Galvanostatic charge-discharge profiles of PB@C and bare PB at $50 \mathrm{~mA} \mathrm{~g}^{-1}$ (0.5 C), and

(f) rate performance of PB@C electrode compared to other PBA cathodes. Reproduced with permission. ${ }^{[129]}$ Copyright 2016, Wiley-VCH.

a

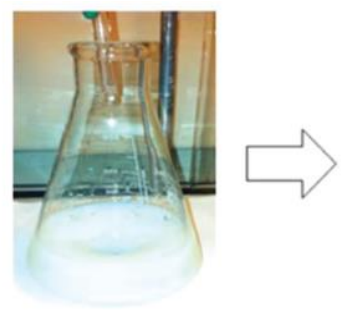

$1 \mathrm{~g} /$ batch

b

Cathode coating

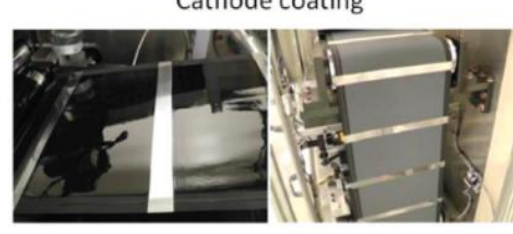

c

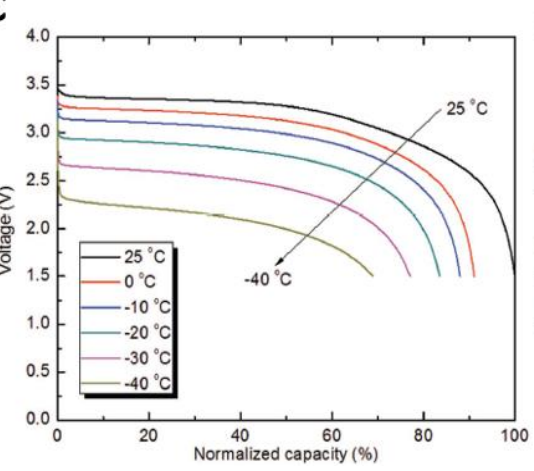

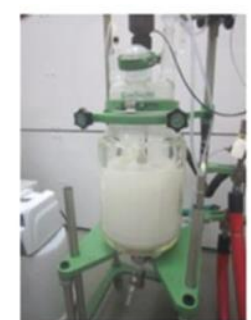

$10 \mathrm{~kg} / \mathrm{batch}$

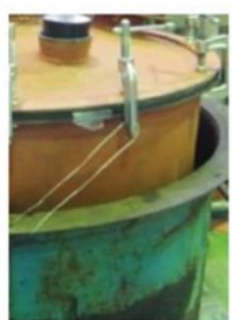

$100 \mathrm{~kg} / \mathrm{batch}$

Pouch cells

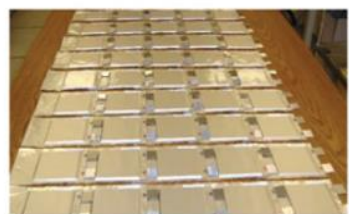

d

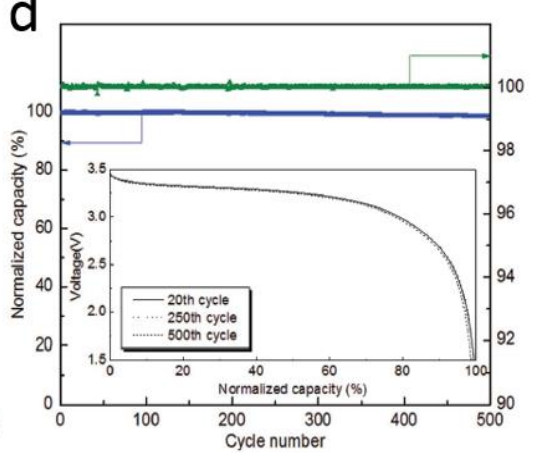

Figure 6. (a) Images of synthesis at different scales; (b) photographs of pilot line for electrode and pouch cell fabrication; (c) pouch cell performance at different temperatures at the $1 \mathrm{C}$ rate and (d) pouch cell cycling performance at room temperature for PBAs made by Novasis. Reproduced with permission. ${ }^{[136]}$ Copyright 2018, Wiley-VCH. 


\section{WILEY-VCH}

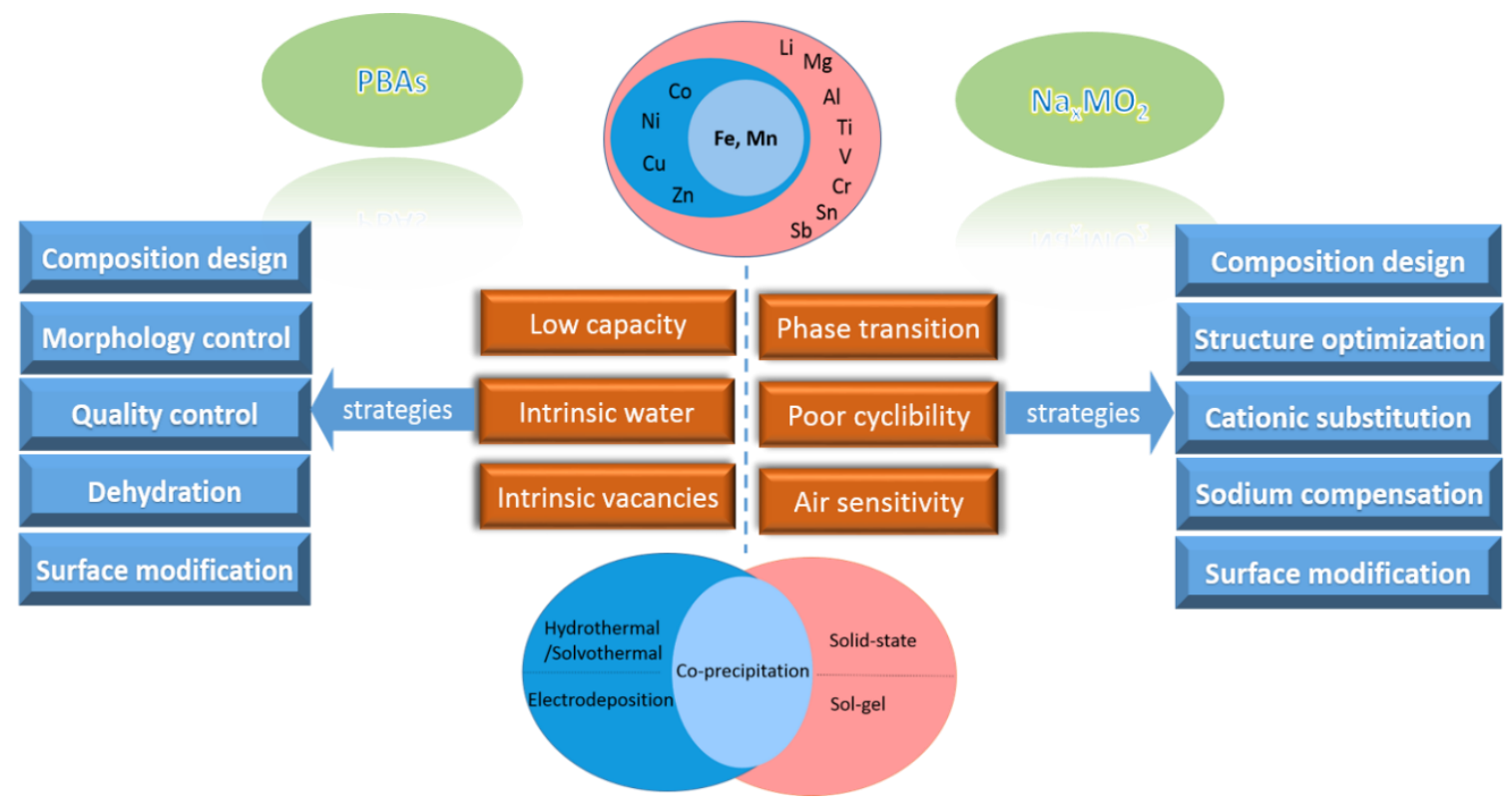

Figure 7. Summary of utilized elements, intrinsic drawbacks, exploited strategies to enhance electrochemical performance, and synthesis methods for PBAs and layered $\mathrm{Na}_{x} \mathrm{MO}_{2}$.

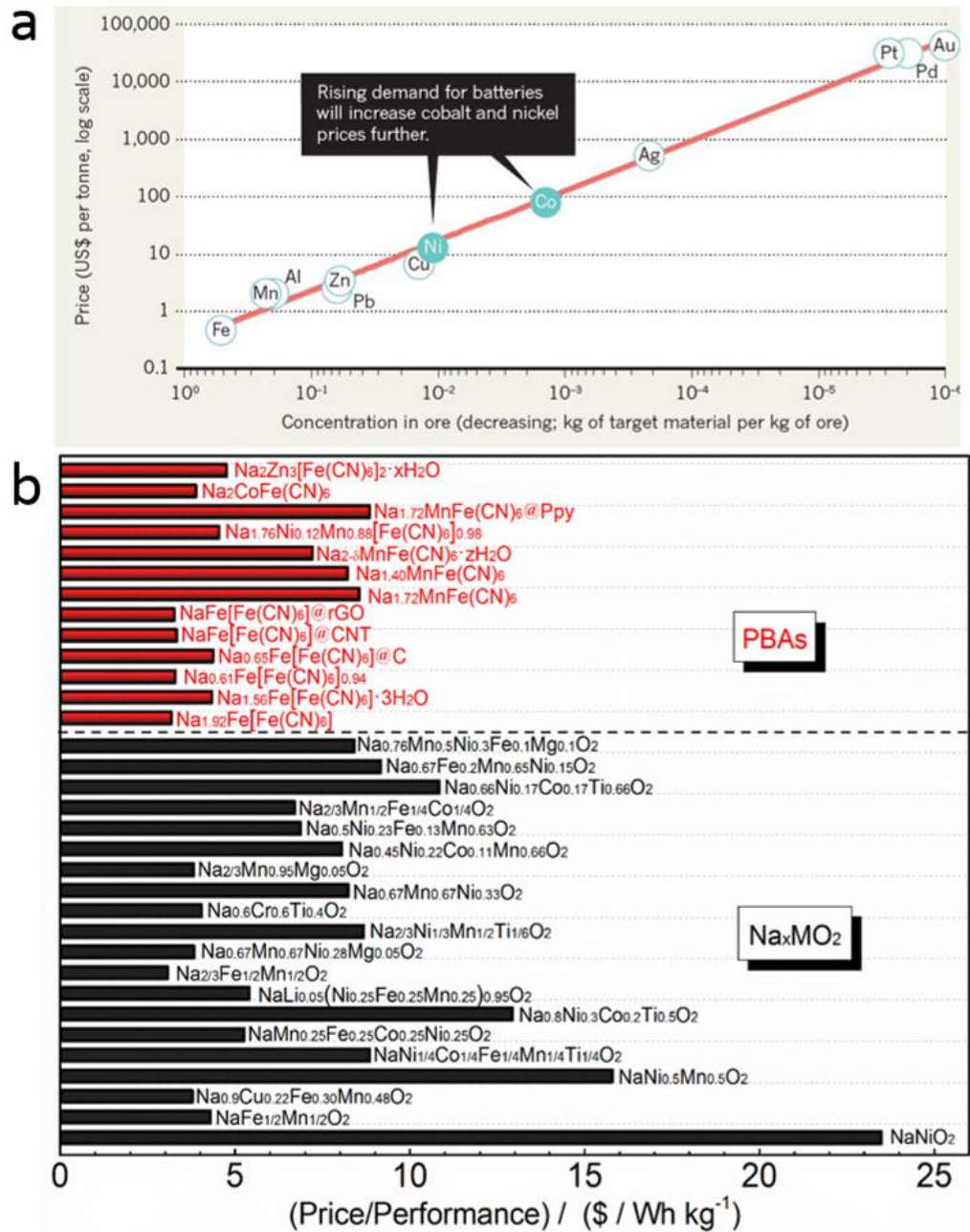




\section{WILEY-VCH}

Figure 8. (a) The relationship between price and concentration in ore of different metals.

Reproduced with permission. ${ }^{[152]}$ Copyright 2018, Nature Publishing Group. (b) The price/performance ratios for typical PBAs and $\mathrm{Na}_{x} \mathrm{MO}_{2}$. Reproduced with permission. ${ }^{\text {[92] }}$ Copyright 2017, Wiley-VCH.

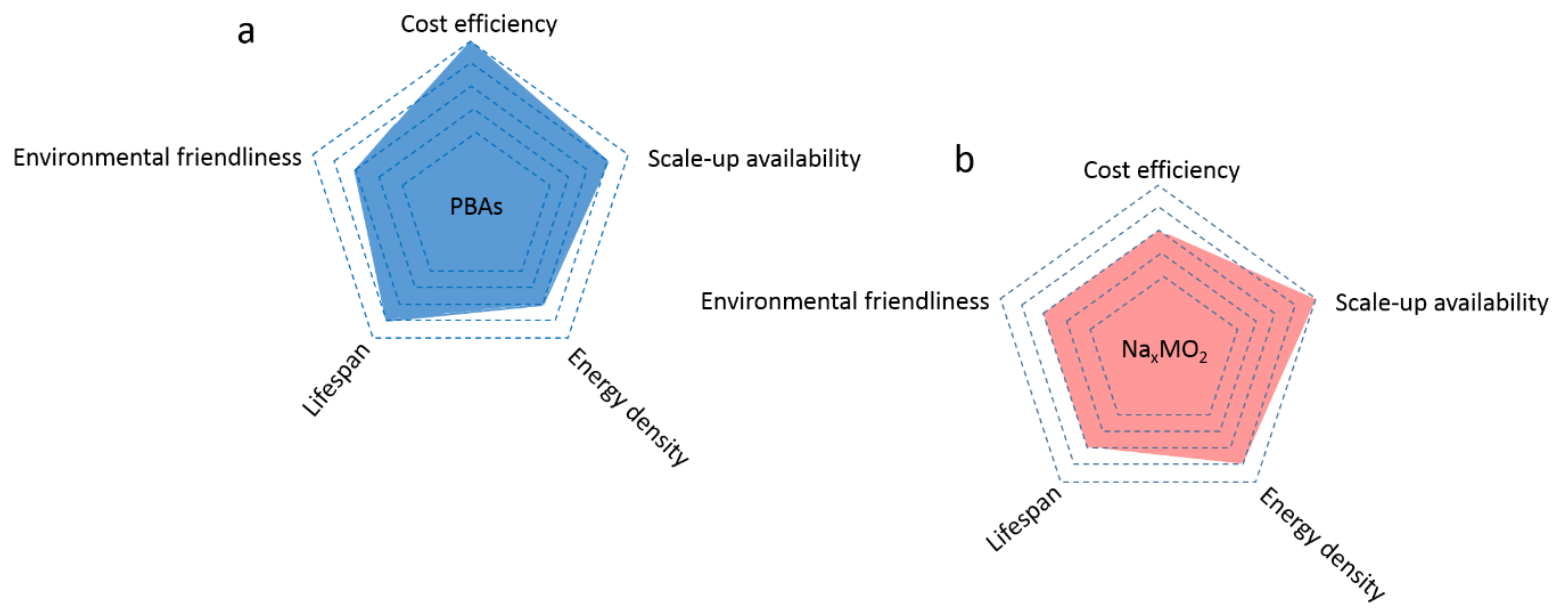

Figure 9. Evaluation and comparison of different aspects of PBAs (a) and $\mathrm{Na}_{x} \mathrm{MO}_{2}$ (b) for SIB commercialisation.

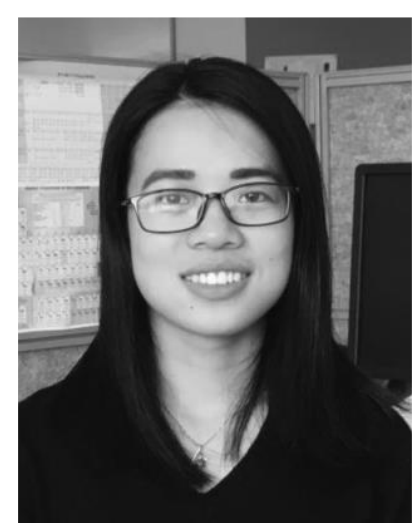

Qiannan Liu is a post-doc research fellow under the joint supervision of College of Chemistry and Materials Engineering, Wenzhou University and Superconducting and Electronic Materials (ISEM), University of Wollongong (UOW). She received her Bachelor's degree (2011) and Master's degree (2014) in material science from Central South University, China. She obtained her Ph.D. from ISEM, UOW in 2018. Her research focuses on the synthesis and characterisation of electrode materials for sustainable energy storage and conversion applications. 


\section{WILEY-VCH}

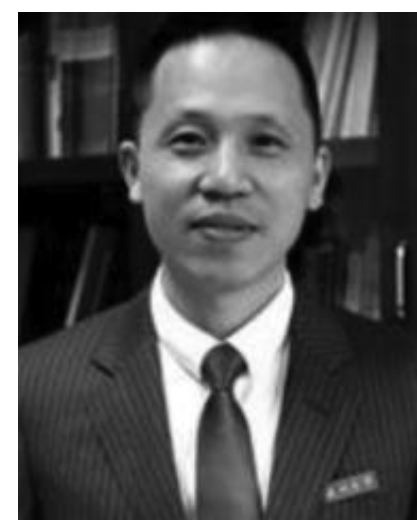

Shun Wang is a distinguished professor at the College of Chemistry and Materials Engineering, Wenzhou University. His research is focused on nanostructured functional materials, including carbon-based nanocomposites, functional Te nanocrystals, hierarchically structured and assembled materials for electrochemical energy storage and conversion technology.

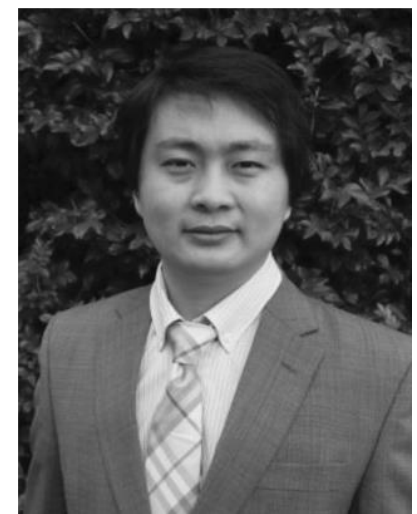

Shu-Lei Chou is a Professor at the Institute for Superconducting and Electronic Materials (ISEM), University of Wollongong. He obtained his bachelor's (1999) and master's degrees (2004) from Nankai University, China. He received his Ph.D. from the University of Wollongong in 2010. His research focuses on energy-storage materials for battery applications, especially on novel composite materials, new binders, and new electrolytes for Li/Na batteries. 


\section{WILEY-VCH}

Layered transition metal oxides and Prussian blue analogues are reviewed in terms of their commercial potential as cathode materials for sodium ion batteries. Recent research progresses, and their electrochemical performance, scale-up availability, cost, and environmental concern are discussed in detail and prospected. It is anticipated that this review will inspire the development and provide guidance for their emerging commercialization.

Keyword: commercialization, cathodes, sodium ion batteries, transition metal oxides, Prussian blue analogues

Qiannan Liu, Zhe Hu, Mingzhe Chen, Chao Zou, Huile Jin, Shun Wang,* Shu-Lei Chou,* Yong Liu,* and Shi-Xue Dou

The Cathode Choice for Commercialization of Sodium-Ion Batteries: Layered Transition Metal Oxides vs. Prussian Blue Analogues

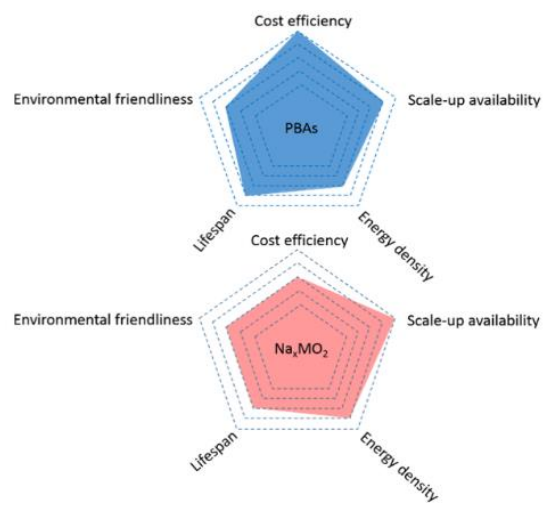

